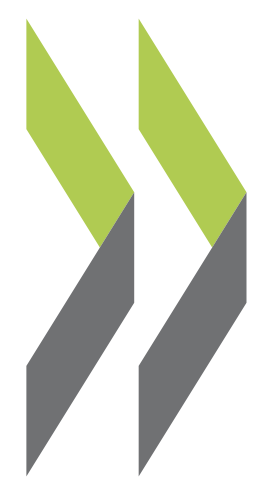

OECD Economics Department Working Papers No. 416

Getting the Most Out of Public Sector

Decentralisation in Japan

\author{
Isabelle Joumard, \\ Tadashi Yokoyama
}


Organisation de Coopération et de Développement Economiques

Organisation for Economic Co-operation and Development

ECONOMICS DEPARTMENT

English - Or. English

GETTING THE MOST OUT OF PUBLIC SECTOR DECENTRALISATION

IN JAPAN

ECONOMICS DEPARTMENT WORKING PAPERS No. 416

By Isabelle Joumard and Tadashi Yokoyama

All Economics Department Working Papers are now available through OECD's Internet Web at http://www.oecd.org/eco 


\section{ABSTRACT/RÉSUMÉ}

\section{Getting the most out of public sector decentralisation in Japan}

Revamping fiscal relations across levels of government is of paramount importance in supporting fiscal consolidation and public sector effectiveness. This paper analyses a number of problems, including regulations that limit local governments' ability to innovate and respond to local citizens' preferences, the inefficient system of intergovernmental grants, the complex structure of local taxes and fiscal rules which are too lenient to secure fiscal discipline. The paper concludes that the grant system should be reformed to promote local governments' incentives to introduce innovations so as to better respond to needs at lower cost. Barriers to the effective use of sub-national governments' taxing powers should be removed while efforts should be made to keep the tax system as simple and neutral as possible. Existing fiscal rules and market instruments should be hardened. This would require that the central government state clearly that it will not intervene as a lender of last resort to local government and ensure adequate information on local governments' outstanding and implicit liabilities is available.

JEL classification: HI, H2, H7, R58.

Keywords: Fiscal federalism, local government, intergovernmental grants, fiscal discipline, Japan.

\section{Optimiser l’impact de la décentralisation au Japon}

La réforme des relations financières entre l'État et les collectivités territoriales est essentielle pour soutenir le processus d'assainissement budgétaire et l'efficacité du secteur public. Ce document met en lumière un certain nombre de problèmes, notamment les réglementations qui limitent la capacité des collectivités territoriales à innover et à répondre aux préférences des citoyens, un système inefficace de transferts intergouvernementaux, une fiscalité locale excessivement complexe et des règles budgétaires trop laxistes. Ce document conclut qu'une réforme du système des transferts est nécessaire pour inciter les collectivités territoriales à innover afin de répondre mieux et à moindre coût aux besoins des citoyens. Les dispositions institutionnelles qui limitent l'utilisation effective des pouvoirs des collectivités territoriales en matière d'impôts doivent être éliminées tout en s'assurant que le système fiscal soit le plus simple et le plus neutre possible. Les règles budgétaires en vigueur doivent être rendues plus strictes et le fonctionnement des marchés financiers amélioré. Cela requiert que l'État annonce clairement qu'il ne jouera pas le rôle de préteur en dernier ressort en cas de difficultés financières des collectivités territoriales et qu'il s'assure de la qualité des informations concernant leurs engagements explicites et implicites.

Classification JEL : HI, H2, H7, R58.

Mots clés: Fédéralisme financier, collectivités territoriales, transferts intergouvernementaux, discipline budgétaire, Japon.

\section{Copyright : OECD 2005}

Application for permission to reproduce or translate all, or part of, this material should be made to: Head of Publication Service, OECD, 2, rue André Pascal, 75775 Paris Cedex 16, France. 


\section{TABLE OF CONTENTS}

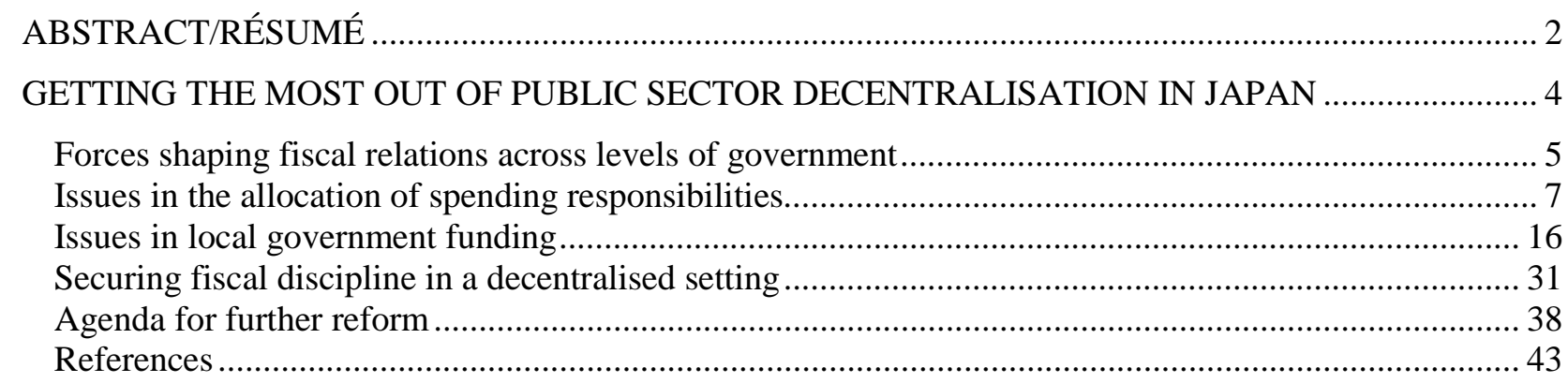

\section{Tables}

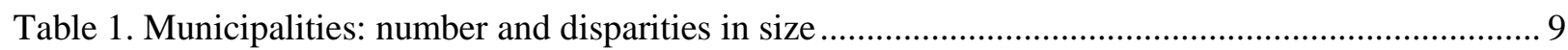

Table 2. Earmarked grants, date of introduction and cost-sharing ...................................................... 13

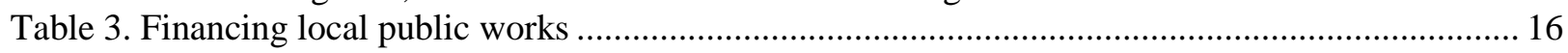

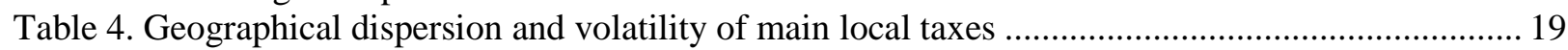

Table 5. Sub-national government taxing powers in selected OECD countries .................................... 22

Table 6. Local government discretionary powers in setting taxes and their effective use ....................... 24

Table 7. Sharing the repayment costs of selected local government bonds ............................................. 35

Table 8. Purchases of local government bonds by type of institution.................................................... 36

\section{Figures}

Figure 1. Subnational government share in general government revenues and expenditure ..................... 5

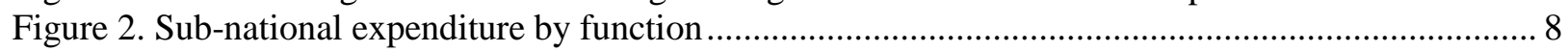

Figure 3. Local government investment: main features ..................................................................... 15

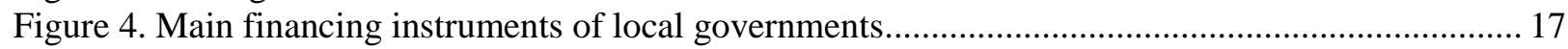

Figure 5. Composition of subnational government tax revenues ........................................................ 19

Figure 6. The equalisation power of intergovernmental grants received by prefectures......................... 27

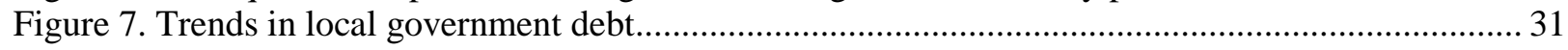

\section{Boxes}

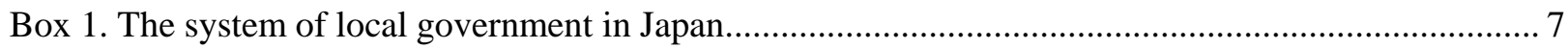

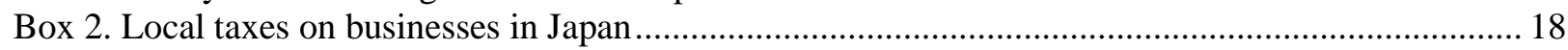

Box 3. Problems with sub-national taxes on business value-added or assets in OECD countries ............. 20

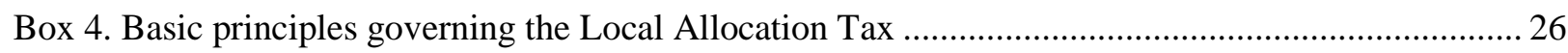

Box 5. Fiscal rules imposed on local governments and regulations for issuing bonds ............................ 33

Box 6. Recommendations for improving fiscal relations across levels of government .......................... 38 


\title{
GETTING THE MOST OUT OF PUBLIC SECTOR DECENTRALISATION IN JAPAN
}

\author{
by Isabelle Joumard and Tadashi Yokoyama ${ }^{1}$
}

1. Government in Japan is unitary with a relatively high degree of decentralisation but the benefits of decentralisation have not been fully exploited while some of its potential risks have materialised. On the spending side, local governments accounted for over 40 per cent of general government outlays in 2002 (Figure 1), a relatively high share among OECD countries and above those in several federal countries (including Austria, Germany and Mexico). The fragmentation in the provision of publicly-funded services, however, has made it difficult to exploit scale economies, with many municipalities too small to be efficient. In addition, strict rules and regulations imposed by the central government have severely limited local governments' ability to innovate and to tailor services to match citizens' needs. On the revenue side, the local government share is smaller but remains high by OECD standards and the right to set local tax bases and rates is broader than in some other OECD countries. The effective use of this taxing power has been rather limited until recently and, when used, it has sometimes increased the complexity of the tax system without serving to discipline local government fiscal behaviour.

2. Ballooning local government debt, from less than 15 per cent of GDP in the early 1990 s to 40 per cent in FY 2003, is another sign of a malfunctioning in fiscal relations across levels of government. Rules on local government budget balances are indeed rather lenient by international standards. Budget constraints have been further softened by the design of the intergovernmental grant system and by the heavy intervention of public bodies to finance local public spending and stabilise the economy, in particular in the 1990s. In this context, local government accountability and incentives to produce services in a cost-effective manner have been weakened.

3. This paper identifies policy options to improve fiscal relations across levels of government. The first section reviews the economic and political context as well as the forces shaping fiscal relations across levels of government. The following three sections present the main issues related to current spending, revenue assignments and existing instruments to secure fiscal discipline. The final section provides conclusions and policy recommendations.

1. This paper was originally produced for the 2005 OECD Economic Survey of Japan, which was published in January 2005 under the authority of the OECD Economic and Development Review Committee. The authors would like to acknowledge Jørgen Elmeskov, Kiichiro Fukasaku, Tomoko Hayashi, Christopher Heady, Hideyuki Ibaragi, Yutaka Imai, Naohiko Jinno, Randall S. Jones, Lamia KamalChaoui, Val Koromzay, Willi Leibfritz, Jørgen Lotz, Nobuki Mochida, Giuseppe Nicoletti, Shin Saito and Motohiro Sato for valuable comments on earlier drafts or for sharing their knowledge. The authors are also grateful to Brooke Malkin for statistical assistance and to Nadine Dufour for secretarial assistance. The paper has benefited from discussion with numerous Japanese experts in ministries and local governments responsible for policy making in this area. 
Figure 1. Sub-national government share in general government revenues and expenditure Percentages, $2002^{1}$

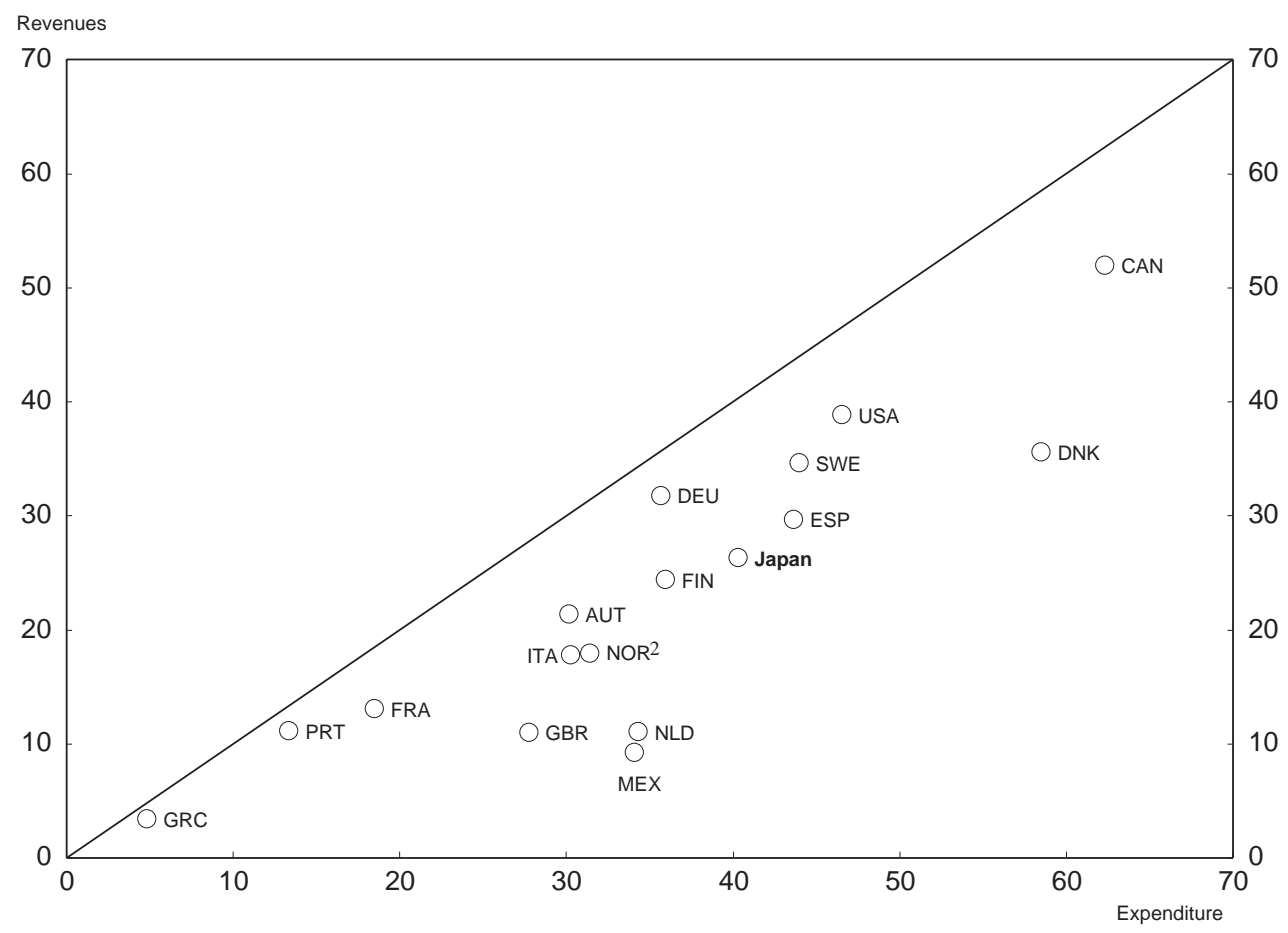

Note: Revenues include direct and indirect taxes as well as non-tax revenues received by regional and local governments and are expressed as a share of revenues received by the general government. Expenditure corresponds to total expenditure by regional and local governments expressed as a share of general government expenditure. Transfers between governments are netted out. The country ranking in this figure does not necessarily correspond to the comparative fiscal autonomy of sub-national governments.

1. Or latest year available: 2000 for Japan and Mexico, 2001 for Portugal.

Source: OECD, National Accounts database; Statistics Norway; Statistics Canada; US Bureau of Economic Analysis.

\section{Forces shaping fiscal relations across levels of government}

\section{Restoring fiscal sustainability}

4. Faced with a gross debt amounting to 157 per cent of GDP in 2003, a continued large deficit and significant spending pressures stemming from the rapid ageing of the population, Japan has to take bold steps to restore fiscal sustainability. Revamping fiscal relations across levels of government is of paramount importance in this regard. In particular, achieving the objective of keeping general government spending fixed as a share of GDP, while promoting economic growth, requires improving the costeffectiveness of local public spending programmes. There is growing recognition that past programmes to stimulate local government spending, and in particular public works, through the grant and local bond systems have had a very limited impact on the growth potential of the Japanese economy. Although the large increase in local public investment during the first half of the 1990s has been largely unwound, further cuts in grants targeted at local public works may be needed, as recognised in the FY 2004 budget, forcing a reallocation across projects and spending areas. 
5. As foreshadowed in the government's Medium-Term Economic and Fiscal Perspective, restoring fiscal sustainability will entail increasing tax revenues. While the Perspective does not specify any change in the tax system, an important consideration should be how to assign tax bases and share revenues across levels of government. The Tax Commission and the 2003 OECD Economic Survey of Japan have both suggested broadening the personal income tax base. Since this alone will not be sufficient to balance the budget, even in the event of significant expenditure cuts, the OECD has also recommended that the consumption tax (VAT) rate be raised at some point. From FY 2004, local governments have been granted a share of personal income tax as a temporary measure until a full-scale transfer of tax resources is implemented. However, this measure and any increase in the consumption tax rate cannot be expected to raise local governments' effective revenue-raising autonomy, and thus accountability, since they have no right to set either the base or rate of these two taxes.

\section{Coping with demographic pressures}

6. Population ageing will change demand patterns for local public services, across both spending categories and jurisdictions. A reallocation of public funds is thus needed to contain spending pressures and to avoid unwarranted disparities in citizens' access to local public services across jurisdictions. The share of the population over the age of 65 is expected to rise from 17.4 per cent in 2000 to 22.5 per cent in 2010 and to 29 per cent in 2025 . The government estimates that social welfare expenditures, including pension, medical care and other welfare programmes, will increase from 86 trillion yen in 2004 (17 per cent of GDP) to 105 trillion in 2010, despite recent reforms. ${ }^{2}$ Pensions would account for about a third of the increase. As employers, local governments' contribution to the pension system amounted to 0.7 per cent of GDP in 2002 and will likely rise significantly over the coming decade, reflecting the pay-as-you-go nature of the system. In addition, since outlays on healthcare and other welfare programmes are largely under local government responsibility, pressure on local spending will be intense. On the other hand, the impact of population ageing could be partially offset by a decline in expenditures on education, which is mainly a local government responsibility. However, while the decline in the number of pupils in primary and lower secondary schools led to the closure of 2125 schools over the past ten years, spending per pupil increased by 20 per cent between 1995 and 2001, keeping overall public expenditure on education constant as a share of GDP. This indicates that, at least until recently, the reallocation of funds has not been sufficient to limit the rise in local spending.

7. Ageing and internal migration flows will affect individual local governments differently, reinforcing demands on equalisation schemes. The share of the population over the age of 65 varies significantly across prefectures, from 25 per cent in Shimane to 13 per cent in Saitama. The share even reaches 40 per cent in some municipalities, with a clear urban/rural cleavage. ${ }^{3}$ At the same time, the increase in the number of elderly people with no family ties is likely to be more rapid in urban centres. In addition, the mobility of citizens across municipalities has increased, resulting in greater divergence between the number of residents and the number of people using local public services and infrastructure, while equalisation schemes are largely based on residents. All of these considerations may call for a reassessment, and possibly a strengthening, of fiscal equalisation schemes across jurisdictions, in particular so as to allow them to provide a certain standard of services for the elderly in rural areas and to avoid infrastructure shortages in urban centres.

2. Even if nominal GDP were to grow at a 2 per cent annual average rate, social security spending would rise to 18.4 per cent by 2010 . However, its share would increase to 21 per cent if nominal GDP, which fell by 3 per cent between 1998 and 2003, were to remain constant through the end of the decade.

3. See Council of Local Authorities for International Relations (2002) and data from the National Governors' Association. 


\section{Bringing government closer to people}

8. There is increasing concern about inefficient spending decisions by the central government (in particular for local public works) and the excessive regulations and uniform standards it imposes on local representatives. With the economy and society maturing, it has become clear that the "one-size-fits-all" approach, used to re-build the country since the Second World War, has increasingly failed to deliver an optimal basket of public goods for local citizens. Distrust of central government bureaucrats has been reinforced by a series of political and corruption scandals. Interestingly, in Japanese elections, the lower the level of government, the higher the rate of voter turnout (OECD, 1997). At this juncture, the transfer of responsibilities to local governments is increasingly seen as a strategy to bring government closer to people so as to respond more quickly and effectively to their demands.

\section{Issues in the allocation of spending responsibilities}

9. Local governments typically face difficulties in efficiently providing public services that are characterised by scale economies, are redistributive by nature and may affect residents from other jurisdictions. In Japan, their core spending items include: education, social welfare, healthcare and a large amount of public works by international standards (Box 1 and Figure 2, Panel A). More than half of total public spending on health, education and social welfare (excluding basic pensions) originates from local governments (Panel B). To exploit scale economies and minimise the risk of a sub-optimal provision of services that are redistributive by nature or whose benefits are shared across several jurisdictions, Japan has relied on three main strategies: promoting amalgamations of municipalities, imposing minimum standards and supporting local spending through generous earmarked grants. This section assesses the benefits and limits of these strategies, largely drawing on experiences in the education sector and public works since they both account for large shares of total local public spending.

\section{Box 1. The system of local government in Japan}

There are two levels of local government. The upper tier consists of 47 prefectures, with population ranging from over 12 million (Tokyo metropolitan government) to 0.6 million (Tottori prefecture). Under the prefectures, there are 2929 municipalities comprised of 712 cities and 2220 towns and villages (as of December 2004), with large variations in terms of population and area size. Despite these variations, all municipalities are basically in charge of the same spending responsibilities and are funded under the same principles. The same applies to the prefecture level.

Total spending by prefectures and municipalities were broadly equal in FY 2002, each amounting to 50 trillion yen (10 per cent of GDP). Local government spending responsibilities include: education, social services (public financial assistance, child welfare, services for the elderly), healthcare services, waste collection and disposal, infrastructure (roads, river management, sewers), public housing and police and fire services. In addition, the National Health Insurance is operated by municipalities. In many of these areas, however, the central government imposes rather strict standards and norms on local government services. Prefectures perform tasks covering wider geographical areas than municipalities but the actual responsibilities often overlap. For example, in the education sector, prefectures are primarily responsible for upper secondary schools while municipalities are responsible for lower secondary and elementary schools. However, most of the teachers' salaries for lower secondary and elementary schools are paid by prefectures and the central government. In the field of waste, municipalities collect and process home garbage while prefectures take the initiative in the disposal of industrial waste. 
Figure 2. Sub-national expenditure by function ${ }^{1}$

A. Composition of sub-national government spending in Japan

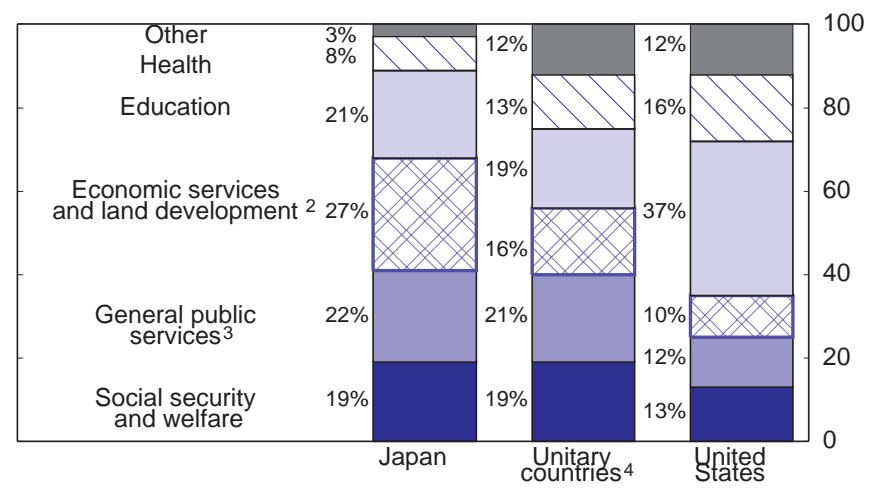

B. Japan: share in selected public spending programmes

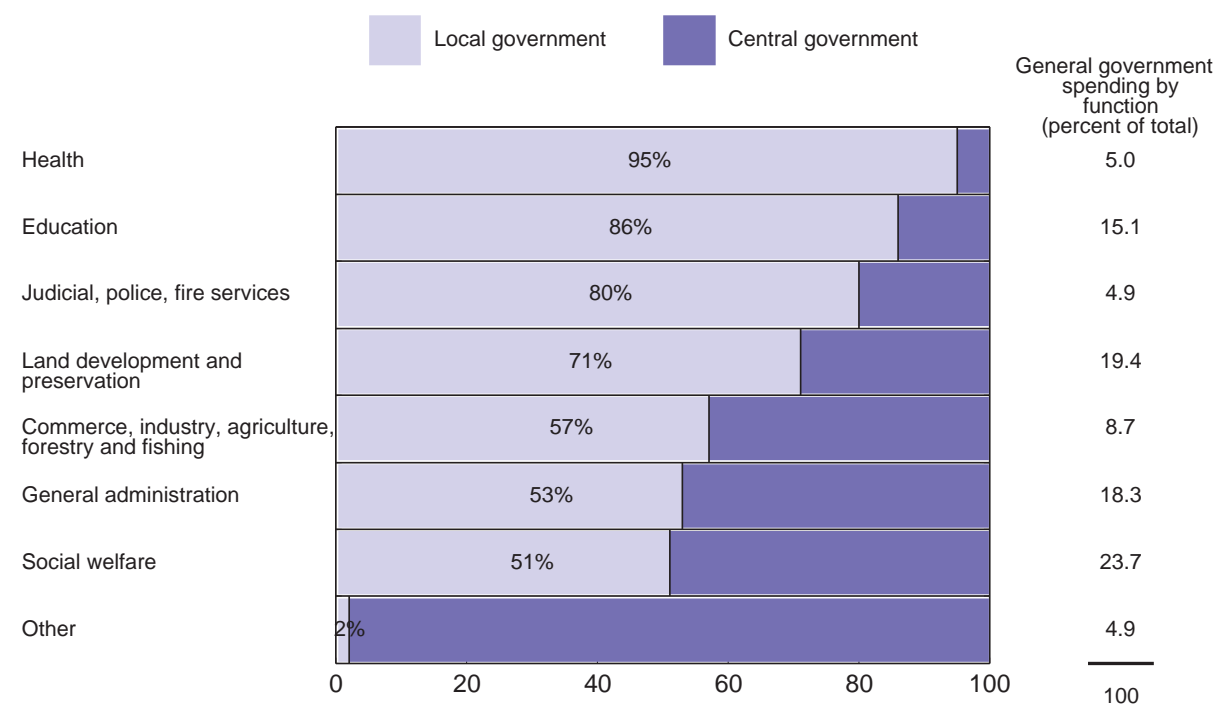

1. FY 2002 for Japan; 2002 or latest year available for unitary countries; 2000 for the United States.

2. Covers general economics, commercial and labour affairs, agriculture, forestry, fishing and hunting, transport, communication. mining, manufacturing and construction, housing and community amenities, etc.

3. Including judicial, police and fire services.

4. Non-weighted average. Includes Denmark, Finland, France, Greece, Italy, Luxembourg, Netherlands, Norway, Spain, Sweden and the United Kingdom.

Source: White Paper on local public finance, 2004, Ministry of Internal Affairs and Communications.

\section{Exploiting scale economies by redesigning the geographical coverage of local public services}

10. The small size of municipalities has made it difficult to secure cost-effective local public services. Some empirical studies have revealed the existence of diseconomies of scale for small municipalities and congestion costs for the largest ones, which have high population density. Hayashi (2002) found that the unit costs of local public services follow a U-shaped curve: they are high for the smallest municipalities, tend to decrease until around 120 thousand inhabitants, and increase as municipalities grow beyond this threshold. Similar results are obtained by Yoshida (2003), who shows that per capita expenditure is the lowest for municipalities with around 125 thousand inhabitants. In 2003, 
93 per cent of municipalities had less than 100 thousand inhabitants and almost half had less than 10 thousand. The small size of municipalities has been at the root of other problems. In healthcare, for instance, it has been identified as one barrier to strengthening the role of municipalities as paying agents and pooling risks effectively (Imai, 2002).

\section{The central government has promoted the amalgamation of municipalities}

11. The central government has long promoted amalgamations so as to ensure that municipalities have sufficient capacity to deliver key public services and exploit scale economies. The number of municipalities was reduced by almost two-thirds during the 1950s (Table 1). The stance in favour of mergers has been strengthened since the end of the 1990s and the ruling parties agreed in July 2000 on a target of reducing the number of municipalities from 3 thousand to 1 thousand, though they did not set a precise timetable.

Table 1. Municipalities: number and disparities in size

\begin{tabular}{lc}
\hline Year & Number of municipalities \\
\hline 1945 & 10520 \\
1953 & 9868 \\
1961 & 3472 \\
1995 & 3234 \\
1999 & 3229 \\
December 2004 & 2929 \\
\hline Percentage of municipalities in April 2003 with: & 47.3 \\
Less than 10 thousand inhabitants & 45.5 \\
Between 10 and 100 thousand inhabitants & 6.5 \\
Between 100 and 500 thousand inhabitants & 0.7 \\
Over 500 thousand inhabitants & \\
\hline
\end{tabular}

Memorandum items:

Number of municipalities considering formally an amalgamation as of April 2004

1. At present, there are 580 Statutory Councils on amalgamation, covering 1855 municipalities. If all of the amalgamation proposals are approved by the Councils, 580 new municipalities would be created from the 1855 (the process is expected to be completed in March 2005). A large number of other municipalities have taken less formal steps to examine amalgamation opportunities: as of October 2004, 193 had set up a Study Group composed of mayors and chairpersons of local assemblies and 71 had set up a Voluntary Council composed of the members of the Study Groups as well as business representatives, academics and citizens.

Source: Ministry of Internal Affairs and Communications.

12. The amalgamation process has been supported by several political and financial measures. The Special Law for Municipal Mergers was revised in 1999 to allow residents to take the initiative in proposing mergers. Municipal assemblies should decide whether to organise a council to consider amalgamation if at least 2 per cent of eligible voters in a municipality sign a petition favouring such a step. To limit opposition by members of municipal councils, the number of seats in the first election following the merger can be up to twice the number allowed by law. On the financial side, adjustments in the grant system were made so as to reduce disincentives to amalgamation, thereby strengthening the incentives for merging small units that are inefficient. ${ }^{4}$ In addition, the central government allows local governments to issue "special amalgamation bonds" for projects related to amalgamation, with 50 to 70 per cent of the

4. The Basic Research Report of the Study Group on amalgamation of municipalities around Tanabe city in Wakayama prefecture, produced in 2002, provides evidence of the still generous treatment for small municipalities. 
redemption costs covered by the central government through the grant system. As a result, 144 municipalities merged to form 42 municipalities between April and October of 2004, 1855 municipalities organised councils to consider amalgamation and 264 others were considering mergers as of October 2004.

13. Amalgamation may not always be the best option to exploit scale economies since both the optimal size and functional areas differ from service to service (e.g. water supply versus education). Co-operative arrangements have the advantage of being more flexible in this respect - they can be singlepurpose or cover several services. In addition, by reducing the number of local governments, amalgamations may weaken competitive pressures and the local democratic process - two of the most well recognised benefits of fiscal devolution, although the optimal size of a municipality in these respects is difficult to determine.

\section{Co-operative approaches have received less attention}

14. The potential benefits of co-operative approaches for providing public services have not been fully exploited. One main form of co-operative agreement is the joint provision of one or several services by a body regrouping a number of local governments on an ad hoc basis. Local governments in Japan, as in a number of other OECD countries, sometimes jointly provide specific public services (e.g. elderly care, waste disposal, fire services, water provision and treatment). ${ }^{5}$ They have not always been efficient. In a number of cases, local public enterprises or the so-called "third-sector companies" (jointly owned by the public and private sectors) have been instrumental in managing these tasks. They have, however, often recorded large losses and associated liabilities that may have to be eventually absorbed by local governments. ${ }^{6}$ Akai (2003) provides evidence that the profitability of these third-sector companies declines when local governments' participation is fragmented. Contributing to this situation is the lack of a clear accountability framework and, in particular, the absence of strict rules for risk-sharing in joint venture projects between the public and private sectors.

15. Other forms of co-operative arrangements that may spur competition across providers, and thus cost effectiveness in local public spending, while mitigating accountability concerns, have received less attention. The "Swiss model", which relies on a purchaser/provider split, is of particular interest. ${ }^{7}$ Under this approach, the supply of services is concentrated in certain jurisdictions - thus allowing scale economies - while providers receive some compensation from other jurisdictions which use these services, so as to mitigate the risk of under-provision. Non-providing jurisdictions can buy services from different providers/jurisdictions (local citizens can also be given the choice of providers through an implicit voucher), thus introducing competition. One disincentive to this approach in Japan, however, is the grant formula which bases entitlements on several criteria, including the number of providers (in particular the number of schools). A local government that decides to stop supplying a specific service while giving its citizens the ability to buy it from another jurisdiction or private provider would thus suffer from a cut in grants.

5. Joint provision of a large number of public services is frequent in France where municipalities are extremely small (less than 2 thousand inhabitants on average) as well as in other OECD countries (including Finland for hospital care).

6. Democratic accountability has been another cause of concern in a number of countries since intergovernmental bodies are not elected by the population. The entanglements of special bodies with different legal backgrounds and territorial coverage could leave citizens with little influence over local and regional public services. See Le Saout (1998) for a discussion on this issue for France.

7. This form of co-operative arrangements across cantons has been implemented for several services, including tertiary education and hospital care. For information concerning such co-operative arrangements, see OECD (2002). 
ECO/WKP(2005)3

\section{Norms and regulations imposed on services provided by local governments}

\section{Norms and regulations have been used extensively to secure equity and promote national objectives}

16. While the local government share in total public spending is high by international standards, decision-making authority has tended to rest with the central government, at least until recently. Major local government public spending programmes (including education, social welfare and public works) are formulated by national ministries and largely financed through earmarked grants. Norms and regulations have often been used to secure minimum standards of public services throughout the country so as to promote equity. For most welfare benefits provided by local governments, eligibility criteria and benefit levels are set by the Ministry of Health, Labour and Welfare. The Livelihood Protection Law even forbids local governments to set benefit levels above the standard level. In the education sector as well, full equality of opportunities has long been the credo of the Japanese system. A uniform system was legislated after the Second World War with strict standards for school curriculum, textbooks and teacher qualifications. This has resulted in a rapid and broadly-based rise in the educational level of the population, providing a solid base for the rapid economic growth of post-war Japan. ${ }^{8}$

17. Norms and regulations have made it difficult for local governments to respond to local citizens' needs and introduce innovative managerial approaches in some areas. The excessive uniformity of schooling has been a cause of concern, including for the central government (OECD, 2001), since it may hinder the diversification of the economy and the innovation process. Although local governments are responsible for appointing teachers, flexibility in setting wages is rather limited because a law instructs local governments to set wages for teachers above the level for other local government employees. The reliance on norms to promote equity has reached its limits. Dissatisfaction with the public school system is reflected by the fact that the share of pupils enrolled in private institutions is high by international standards -27 per cent in 2003, compared to below 10 per cent in Canada, Italy and the United States. With tuition fees for these schools being much more expensive than for public schools, experience in other OECD countries shows that there is a risk of social segregation in the education system.

\section{Recent deregulation initiatives have yet to yield their full benefits}

18. Several commendable deregulation initiatives - giving local governments more autonomy in designing and managing their spending programmes - have been launched since the mid-1990s. The Omnibus Decentralisation Act in 1999 aimed at clarifying the respective roles of central and local governments and reducing central government involvement in the provision of public services. In the education sector, efforts have aimed at ensuring that schools work more closely with their local communities and at promoting creativity, diversity and flexibility so as to give Japan a competitive edge in the globalisation process. Central government regulations regarding school hours and curriculum were loosened (OECD, 2001 and Shimizu, 2001). ${ }^{9}$ Local boards of education were also allowed in 1997 to expand the opportunities for children to register in schools outside their designated catchment areas in order to take account of parental preferences.

19. The Special Zone initiative begun in 2002 (OECD, 2005) has given local governments new opportunities to lower the regulatory burden and tailor their actions to better suit citizens' preferences. In

8. Recent cross-country analysis shows that Japan has succeeded in combining a high level of education with low disparities across the country by OECD standards. See OECD (2003), Education at a Glance.

9. The 1998 report by the Central Council for Education recommended that the Ministry of Education limit its practice of giving detailed advice to lower levels as well as minimise the participation by the national and prefectural governments in the activity of municipalities and schools. It introduced a new course of study, allowing schools some flexibility in designing curriculum and length of class time. 
the education sector, it allows local governments and the private sector to offer new types of schools and several municipalities have already announced plans to launch schools that prioritise teaching English. Of the 1695 proposals for special zones made through November 2003, 209 concerned the education sector. However, experience with the Special Zone initiative has not only demonstrated that there are a large number of regulatory constraints on growth identified by the local authorities but has also revealed that local governments often lack appropriate information on regulations, since some have asked to be exempted from regulations which did not exist.

20. Several local governments have exploited their new discretionary powers. The education board of Shinagawa ward in Tokyo has been one of the most active in this respect. It introduced school choice in its public elementary schools in 2000 and in its lower secondary schools in 2001 and reformed personnel management rules. In many other local governments, however, there is a strong tendency to wait for instructions from the Ministry of Education (Muta, 2000). ${ }^{10}$ Time may help, as local public employees learn by doing and citizens fully understand where responsibilities lie and seize the opportunity to voice their preferences. The lack of expertise in the smallest jurisdictions may, however, need to be tackled, for example through amalgamations (see above).

\section{An extensive use of earmarked grants}

21. Earmarked grants have been used extensively to steer local government spending decisions. They amounted to 40 per cent of intergovernmental transfers in FY 2002 (over 2.6 per cent of GDP) - a high share compared to many other OECD countries. ${ }^{11}$ In principle, these grants have two main objectives: to minimise the risk of a suboptimal provision of public services when their benefits extend beyond a jurisdiction's boundaries (spillover) and to secure minimum standards for specific services (Cabinet Office, 2001). In practice, however, these grants have been extensively used for macroeconomic stabilisation and for regional redistribution purposes, which can create conflict between objectives - the case of local public works being a case in point (see below). In addition, rigidities in the allocation process and the lack of proper cost-benefit analysis have limited the effectiveness of these grants in addressing spillover effects. Indeed, almost 60 per cent of the earmarked grants aiming to promote specific activities were established before 1980 (Table 2). The flexibility in allocating resources across sectors has increased somewhat since 2000. In particular, the FY 2003 budget introduced a mechanism to facilitate the shift of discretionary spending toward priority areas by enabling the Ministry of Finance to approve requests from other ministries for spending increases of up to 20 per cent. More progress is, however, needed as recognised in the Structural Reform Evaluation Report by the Cabinet Office in 2004.

10. Muta (2000) notes that after the introduction of flexibility in designing curriculum at a local level, local boards of education and schools sent so many requests for assistance to the Ministry of Education that a publication was distributed in 2000 and became a best seller.

11. Several OECD countries (including Canada, Finland, Iceland, Ireland, Norway and Sweden) drastically reformed their grant system in the 1990s, replacing most earmarked grants by general-purpose grants (Joumard and Kongsrud, 2003). The United States is the main exception in this regard. 
ECO/WKP(2005)3

Table 2. Earmarked grants, date of introduction and cost-sharing Billion yen ${ }^{1}$

\begin{tabular}{|c|c|c|c|c|c|c|}
\hline \multirow[b]{2}{*}{ Time of introduction } & \multicolumn{4}{|c|}{ Central government contribution rate to total costs } & \multirow{2}{*}{ Total } & \multirow{2}{*}{$\begin{array}{c}\text { Memorandum } \\
\text { item: } \\
\text { Share } \\
\text { (per cent) }\end{array}$} \\
\hline & $\begin{array}{c}\text { Less than } \\
1 / 3\end{array}$ & $\begin{array}{c}1 / 3 \text { or more } \\
\text { but less } \\
\text { than } 1 / 2\end{array}$ & $\begin{array}{c}1 / 2 \text { or more } \\
\text { but less } \\
\text { than } 1\end{array}$ & 1 & & \\
\hline $\begin{array}{l}\text { Before } 1954 \\
\text { High economic growth period }\end{array}$ & 7.2 & 121.6 & 283.1 & 59.2 & 471.1 & 11.7 \\
\hline $\begin{array}{l}(1955-1973) \\
\text { Oil shock period }\end{array}$ & 37.4 & 263.1 & 401.8 & 561.2 & 1263.5 & 31.4 \\
\hline $\begin{array}{l}(1974-1979) \\
1980-1990 \\
\text { Since } 1990\end{array}$ & $\begin{array}{r}0 \\
0 \\
59.1\end{array}$ & $\begin{array}{r}163.2 \\
98.3 \\
336.4\end{array}$ & $\begin{array}{r}208.4 \\
86.4 \\
234.6\end{array}$ & $\begin{array}{r}215.3 \\
823.8 \\
61.3\end{array}$ & $\begin{array}{r}586.9 \\
1008.5 \\
691.4\end{array}$ & $\begin{array}{l}14.6 \\
25.1 \\
17.2\end{array}$ \\
\hline $\begin{array}{l}\text { Total } \\
\text { Memorandum item: }\end{array}$ & 103.7 & 982.6 & 1214.3 & 1720.8 & 4021.4 & 100.0 \\
\hline Share (per cent) & 2.6 & 24.4 & 30.2 & 42.8 & 100.0 & \\
\hline
\end{tabular}

1. The data presented here are for the so-called "national financial subsidies" whose main objective is to promote specific projects. In FY 2000, public works accounted for 40 per cent of the total, social welfare for 25 per cent and 10 per cent was devoted to education and science promotion. The amounts are those set in the initial budget for FY 2000.

Source: Cabinet Office, 2001.

22. These grants are not only earmarked to specific areas (e.g. public works, education or social welfare) but they are made conditional on local governments complying with strict and detailed operational standards. For instance, local government officials have reported difficulties in using grants earmarked to pay teacher wages for part-time teachers. ${ }^{12}$ Under the Law on State Subsidies on Expenditure on Facilities for Compulsory Education, half of the construction costs of school building are paid by the central government if the recipient complies with rather strict conditions such as floor size, availability of various rooms (science room, visual room, consulting room, etc.), equipment and distance from the students' homes. Mihaljek (1997) also noted that in the case of public construction work in general, even the brands of construction materials and parts were sometimes specified by the central government. With various ministries and public agencies involved in the allocation process and detailed operational conditions, earmarked grants do not allow spending programmes to properly reflect local needs. In addition, applying for and managing earmarked grants tends to be cumbersome and costly for local government (Cabinet Office, 2001). ${ }^{13}$

12. The Ministry of Education, Culture, Sports, Science and Technology (MEXT) has removed the conditions that the earmarked grant for teacher wages be used only for full-time teachers, beginning in FY 2004. However, because of a lack of information, a certain number of local governments still believe that the constraint is binding. The Ministry of Education still needs to better inform local governments of the benefits of the new grant system. Furthermore, the central government envisages giving local governments more freedom in setting the wage levels and the number of teachers within the total amount of the grant. A central government law requires that the wages of teachers in the compulsory education system be set above the level of other local public officials with the objective of maintaining a high education standard. In addition, the MEXT sent a letter in 2004 to all local education boards urging them to maintain teacher wages at a "necessary level".

13. A recent survey revealed that a majority of local government representatives would favour the removal of many earmarked grants with compensation in the form of higher block grants and/or local tax revenues. See the paper submitted to the Council on Economic and Fiscal Policy by its private-sector members on 21 November 2003. 


\section{ECO/WKP(2005)3}

\section{The case of public works}

23. Public works have absorbed a significant share of earmarked grants. Local government spending on public works has declined somewhat since the mid-1990s but remains very high by OECD standards (Figure 3, Panel A), reflecting generous support from the central government. Past investment has not, however, fully filled the gap with some OECD countries, at least for some categories of infrastructure. There is evidence suggesting that infrastructure endowments in Japan stood below those in the United States and many continental European countries in 2000 (Nicoletti et al., 2003). Although bottlenecks in infrastructure partly reflect topographic and historical factors, an inappropriate allocation of public works across both regions and sectors has likely played an important role (Cabinet Office, 2001b, and Ministry of Finance, 2001 and 2002). ${ }^{14}$

24. Central government support of local public works has been driven by multiple objectives. Stimulating the economy during recession periods has been an important goal of the central government, in particular in the early 1990s. Reducing dispersion in regional income has also long been a major factor in the allocation of public investment (Kamada et al. 1998). Per capita investment in low-income prefectures was twice that in high-income areas in 1998 despite a much higher rate of return in the latter (Figure 3, Panel B). The bias in favour of low-income/rural regions, which increased in the late 1990s (Panel C), resulted in part from features of the Japanese political system and the lobbying activities of local interest groups (Doi and Ihori, 2002; Robaschik and Yoshino, 2004). The high level of investment in poorer areas has not stimulated self-sustaining growth as hoped, as the areas simply became highly dependent on public works and construction companies in rural areas captured most of the rent (Yoshino and Sakakibara, 2002). Several empirical studies show that the impact of public investment on the country's potential growth has declined substantially since the early 1990s to a low level, suggesting that generous central government support to local public works has substantially exceeded territorial spillover effects. ${ }^{15}$

25. Deficiencies in the use of cost-benefit analysis have also been identified. Although such analysis has been mandatory since FY 1999, it is still made by the relevant spending ministries, in contrast with the promising reform recently implemented in Korea. ${ }^{16}$ The underlying assumptions for estimating potential benefits have often been arbitrary and excessively optimistic. The study group on cost-benefit analysis for public investment of the Ministry of Finance recommended in 2002 that the analyses review assumptions on macroeconomic developments and infrastructure targets set by spending ministries and make public the information and methods used (Ministry of Finance, 2002). Following the recommendation, the Ministry has been promoting more effective use of cost-benefit analysis in the budget formulation process.

14. Infrastructure projects are possibly more costly in Japan since the land is mountainous and prone to earthquakes, the ground is soft and rainfall is high. The development of social infrastructure started only in the late 19th century in Japan, much later than in most western nations. Kondo (2002) argues that the provision of public capital is sufficient at the aggregate level but that infrastructure for railways, telephone networks, telegraph and postal services is below the optimal level.

15. See Cabinet Office (2004), Ministry of Finance (2002), Ishii and Wada (1998), Nakazato (2003) for road construction projects, and Yoshino and Sakakibara (2002). The OECD Growth Study shows that the overall impact of public investment on economic growth is extremely low when one accounts for the extra taxes a government will have to impose to finance it (Bassanini et al., 2001).

16. Korea has introduced a preliminary feasibility study system aimed at strengthening the ex ante evaluation process. Since 1999, the Public Investment Management Centre (PIMA) has conducted studies for all new large public investment projects. In most studies, public investment is evaluated from both social policy and economic perspectives. By 2003, PIMA had examined 153 projects, of which 78 were rejected. 
ECO/WKP(2005)3

Figure 3. Local government investment: main features

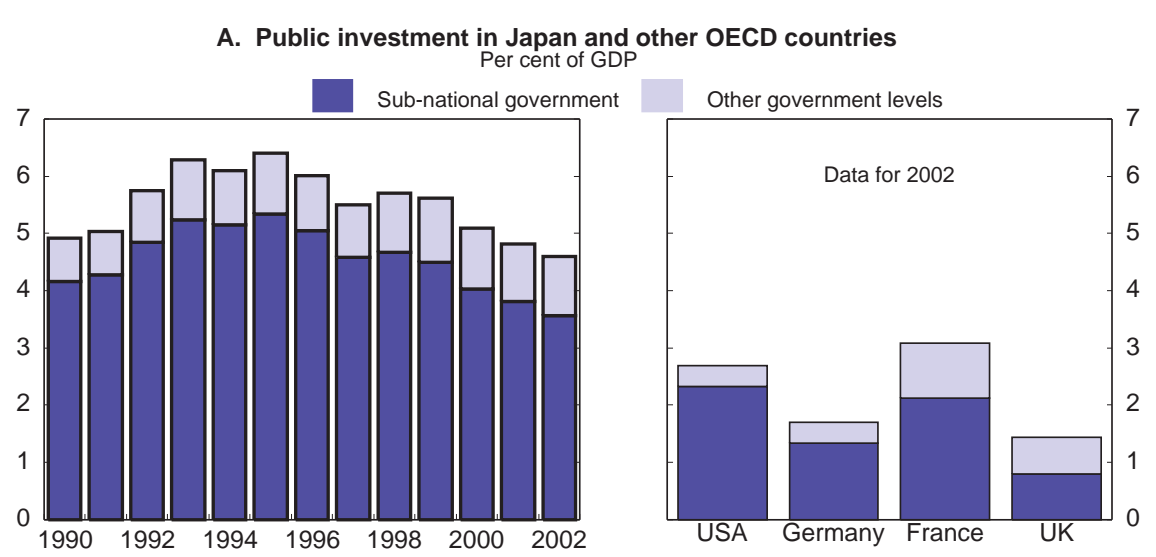

B. The level and return on public investment by prefecture
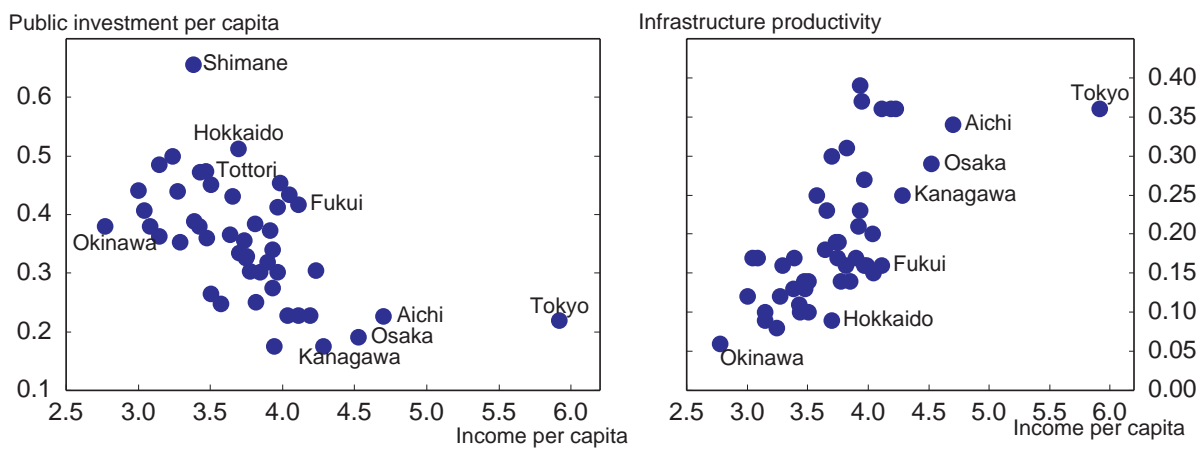

C. Allocation of local public works between rural and metropolitan areas

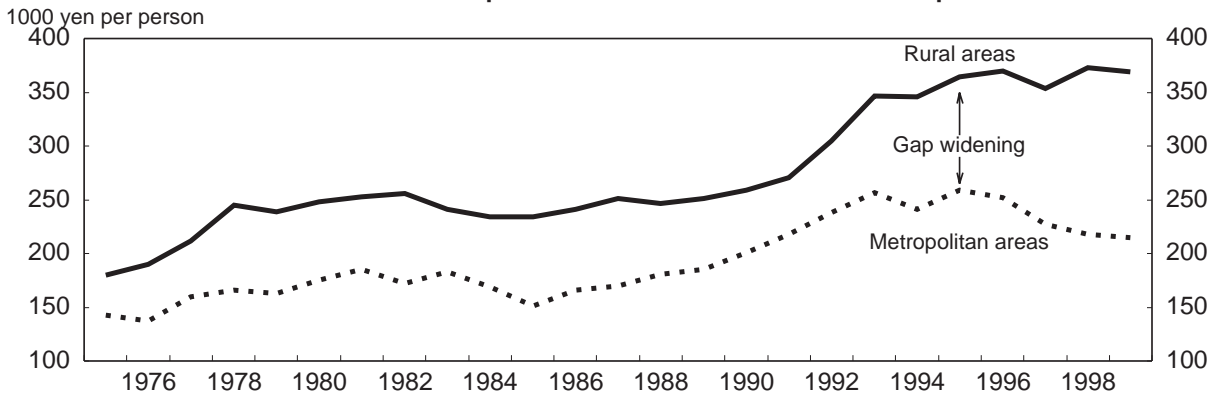

Source: Cabinet Office, Annual Report on Prefectural Accounts, Ministry of Finance, Ministry of Internal Affairs and Communications, Population Census of Japan, and OECD National Accounts.

26. The central government provided increasingly generous financial incentives to support local public works over the 1990s. This support has been channelled through the grant system as well as by permitting local governments to issue bonds with the implicit guarantee and subsidisation from the central government. There are two main categories of public works - the so-called "subsidised" and "independent" projects. While earmarked grants are a key financing source of subsidised public works, their share fell from 51 per cent in FY 1999 to 43 per cent in FY 2002 (Table 3). As a result, local governments have increasingly relied on local bonds to finance both subsidised and independent projects (the latter being ineligible for earmarked grants). Local bonds also involve substantial financial support from the central government. First, debt service and the actual endowment in infrastructure (e.g. length of roads, bridges, 
etc.) enter in the calculation of local governments' entitlements to the main block grant (the Local Allocation Tax, see below). Second, local government debt is implicitly guaranteed by the central government, which thus carries much of the costs in term of the risk premium.

Table 3. Financing local public works

Percentage shares

\begin{tabular}{l|ccc|ccc}
\hline & \multicolumn{3}{|c|}{ "Subsidised" public works } & \multicolumn{3}{c}{ "Independent" public works } \\
\hline & FY 1990 & FY 1999 & FY 2002 & FY 1990 & FY 1999 & FY 2002 \\
\cline { 2 - 7 } & 40.6 & 51.1 & 42.7 & 0.0 & 0.0 & 0.0 \\
Earmarked grants from the central & & & & & & \\
government & 27.9 & 36.0 & 44.3 & 21.3 & 45.4 & 40.8 \\
Local government bonds & 26.1 & 7.5 & 7.7 & 65.9 & 41.5 & 44.5 \\
$\begin{array}{l}\text { Local government general revenues } \\
\text { (including block grants) }\end{array}$ & 5.4 & 5.4 & 5.3 & 12.8 & 13.1 & 14.7 \\
Others & & & & & & \\
\hline Memorandum item: & 1.9 & 2.3 & 1.9 & 2.9 & 2.5 & 2.0 \\
Local public works as a share of GDP &
\end{tabular}

Source: Ministry of Internal Affairs and Communications.

27. Generous financial support has dulled incentives to minimise the costs of local public works. The lack of competition in public procurement has been an important cause of concern. ${ }^{17}$ The $O E C D 2000$ Economic Survey of Japan reported on the possibility of widespread bid-rigging (dango) in public procurement at the local government level. In addition, a vast majority of municipalities have pursued the favourable treatment of local companies and locally produced goods as a policy goal. Overall, it was estimated in 2000 that improvement of the public procurement system could reduce costs by 15 per cent. The Law for Bidding for Public Works Projects adopted in 2000 aimed at improving the transparency and fairness of the bidding process. Industry sources, however, still complain of problems with securing public procurement contracts at the local government level, including lack of transparency, unclear procedures and close ties between commissioning entities and incumbent firms. ${ }^{18}$ The large degree of regional variation in requirements and processes further contributes to the arbitrary operation of the tender process.

\section{Issues in local government funding}

28. With large spending responsibilities at the local level, the main challenge on the funding side is to provide local governments with sufficient revenue-raising autonomy to make them accountable to local citizens, while ensuring that all have enough capacity to raise revenue to provide a certain level of core public services. Local governments have long relied on local taxes, in particular income taxes. The economic slump, however, has been reflected in a stagnation in local tax revenues in real terms since the early 1990s (Figure 4). Meanwhile, local financing needs increased since local spending was promoted by the central government, at least until the late 1990s, in part to cushion the sluggishness of other demand components. Block grants and local bonds have thus played an increasing role in filling local government financing gaps.

17. See, for instance, the fifth Comprehensive National Development Plan, "Grand Design for the 21st Century", adopted in 1998.

18. See the European Business Community in Japan (2003). 
Figure 4. Main financing instruments of local governments At 1995 constant prices, using the GDP deflator

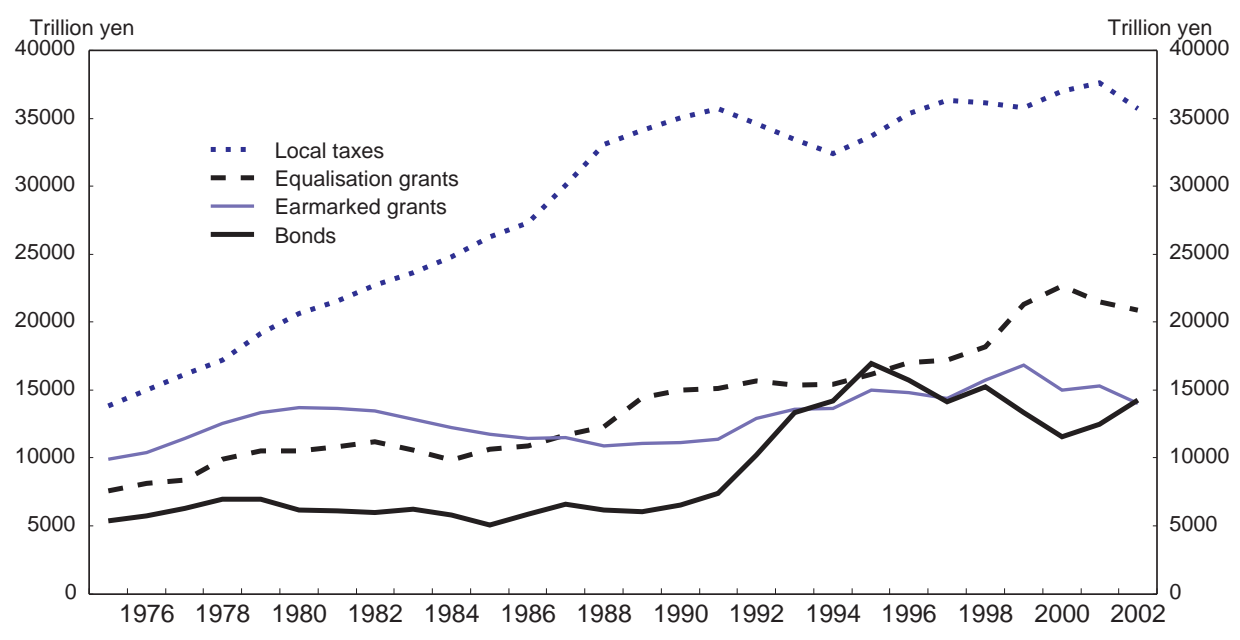

Source: Cabinet Office and Ministry of Internal Affairs and Communications.

\section{A complex system of local taxes}

29. Local taxes are numerous but their revenues fall short of local government spending by a considerable amount. The Local Tax Law - a national law - defines the tax bases and standard rates for 13 main prefectural taxes and for ten municipal taxes. ${ }^{19}$ This contrasts with a much leaner local tax system in Nordic countries - at most four local taxes in Finland, Iceland, Norway and Sweden - which are, like Japan, unitary countries with a high share of local government in total public spending. This rather complex local tax system results in some duplication and overlapping of tax bases - corporate income, for instance, being subject to the two inhabitant taxes on corporations (at the municipal and prefectural levels) and to the prefectural enterprise tax (Box 2) ${ }^{20}$ The proliferation of deductions and exemptions, which has also plagued some of the central government taxes, has damped local government revenues. As an indication, only 30 per cent of companies paid the prefectural enterprise tax on profits in FY 2001. The prefectural and municipal inhabitant taxes on individuals also contain many allowances, with about a quarter of the workforce not paying any income tax (Nagaosa, 2003) ${ }^{21}$ Furthermore, the value of land for

19. Prefectural taxes prescribed by the Local Tax Law are: the inhabitant tax on individuals, the inhabitant tax on companies, the enterprise tax, the local consumption tax, the real property acquisition tax, the tobacco tax, the golf course utilisation tax, the automobile tax, the automobile acquisition tax, the mining tax, the hunter registration tax, the hunting tax and the light-oil delivery tax. Municipal taxes prescribed by the Local Tax Law are: the inhabitant tax on individuals, the inhabitant tax on companies, the property tax, the light vehicle tax, the tobacco tax, the mineral product tax, the special landholding tax, the hot springs tax, the urban planning tax and the business office tax. The Local Tax Law also defines standard tax rates which are used to derive Standard Fiscal Revenue, and thus grant entitlements, of each local government (see below). Although local governments do have the possibility to set some local tax rates below or above the standard ones, they have exercised this power only to a limited extent.

20. Companies are further subject to the national corporate income tax although the three local taxes on companies are deductible from taxable income at the national level.

21. These tax allowances are very similar to those for the national individual income tax -- in particular a high tax-exempted income threshold, generous deductions for pension income and the "regular" spouse allowance -- which were considered as excessive by the Tax Commission in 2003 (Tax Commission, 2003). 
tax purposes in the immovable property tax is set at 60 to 70 per cent of the reference price provided by the Ministry of Land, Infrastructure and Transport. Local governments can and do, to a limited extent, increase rates for a number of taxes, thus compensating for some of the loss in revenue resulting from undervaluation or exemptions. This strategy may, however, meet fierce political resistance (in particular for one of the most visible taxes, the property tax) and raise serious economic concerns.

\section{Box 2. Local taxes on businesses in Japan}

Companies are subject to three or four main local business taxes according to the size of the municipality in which they are located.

The municipal inhabitant tax on companies comprises two components. The first is a tax on business income, calculated as a flat surcharge on the national corporate income tax. The Local Tax Law sets the standard rate at 12.3 per cent and gives local governments the possibility to increase the rate up to 14.7 per cent. The second component is a tax on companies' assets (own capital), with tax liabilities increasing in line with the value of assets.

The prefectural inhabitant tax on companies is broadly similar to the municipal one and uses the same tax base for the business income component. The standard rate is set at 5 per cent with a ceiling of 6 per cent. Tax liabilities for the asset component are calculated somewhat differently than at the municipal level since they increase with both the number of employees and the value of the company's assets.

The prefectural enterprise tax was, until April 2004, a pure income tax based on a similar definition of the company's income to that used for the national corporate income tax. Standard tax rates were progressive relative to the company's income (from 5 to 9.6 per cent). The enterprise tax was reformed in FY 2004 for large companies (i.e. own capital above 100 million yen) so as to secure more stable revenues for prefectures and to implement the principle of benefit taxation - every company using local public services should pay taxes whether or not it makes profits. For these companies, the enterprise tax now has three components: i) an income component taxed at a reduced rate compared with the previous system (3.8 to 7.2 per cent depending on the company's income); ii) a 0.48 per cent tax on the company's value-added (defined as the sum of employee compensation, net interest payments, rents and profits or losses); iii) a 0.2 per cent tax on the company's assets. As with the previous enterprise tax, prefectures are permitted to raise the tax rate up to 20 per cent above standard rates. When firms operate in more than one prefecture, tax revenues are shared across them taking into account the number of employees and the value of fixed capital.

For companies located in large cities (i.e. with a population of more than 300 thousand), a municipal enterprise tax is imposed. The first component is based on the size of the company's building (600 yen per square metre) and the second component is a tax on the wage bill ( 0.25 per cent of the total). Municipalities have no right to alter the tax base or rates of the municipal enterprise tax.

\section{The high volatility of local tax revenues and regional imbalances}

30. Revenues of some of the main local taxes have fluctuated sharply over the economic cycle. Business taxes amounted to 20 per cent of local government tax revenues in 2001, which is a very high share by international standards (Figure 5), and have been the most volatile component over the past 15 years (Table 4). The 2004 reform of the enterprise tax is expected to reduce this volatility by lowering the income component and introducing an asset component - similar to those used for the prefectural and municipal inhabitant taxes on corporations - and a value-added component (see Box 2). It should, however, be noted that the prefectural inhabitant tax on corporations has been rather volatile in the past. 
ECO/WKP(2005)3

Figure 5. Composition of sub-national government tax revenues 2002

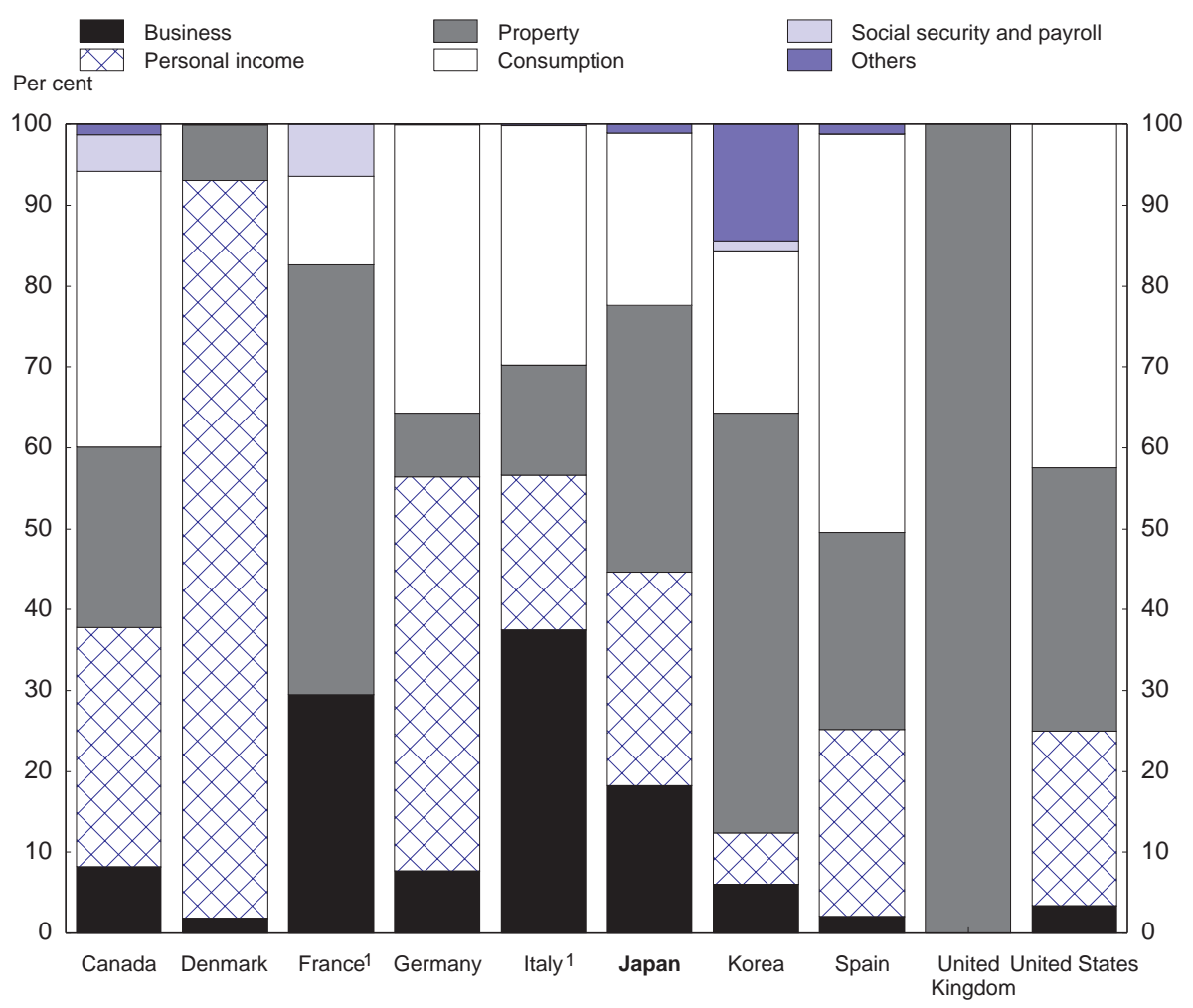

1. Including other taxes paid solely by business (Taxe professionnelle in France and IRAP in Italy). Source: OECD Revenue Statistics, 1965-2002.

Table 4. Geographical dispersion and volatility of main local taxes

\begin{tabular}{lcc}
\hline Main prefectural and municipal taxes & $\begin{array}{c}\text { Geographical dispersion } \\
\text { FY 2002 }\end{array}$ & $\begin{array}{c}\text { Volatility over time } \\
1985-2002^{2}\end{array}$ \\
\hline Inhabitant tax on individuals & 0.27 & 0.09 \\
Inhabitant tax on companies & 0.40 & 0.21 \\
Enterprise tax & 0.49 & 0.26 \\
Local consumption tax (VAT) & 0.16 & 0.07 \\
Property tax & 0.19 & 0.13 \\
Total local taxes & 0.22 & 0.05 \\
\hline
\end{tabular}

1. Geographical dispersion is measured by the coefficient of variation of the revenue per capita in each of the 47 prefectures from each local tax.

2. Volatility over time is measured by the coefficient of variation for the ratio of local tax revenues to GDP over the period 1985-2002, except for the local consumption tax. To adjust for the change in the local consumption tax rate in 1997, volatility has been calculated by averaging the volatility over the periods 1991-96 and 1998-2002.

Source: Calculations based on data from OECD Revenue Statistics and from the Ministry of Internal Affairs and Communications. 
31. While the reformed enterprise tax is expected to yield more stable revenues for local government, it also raises a number of concerns which have led some OECD countries to abolish or reform drastically similar business taxes (Box 3). First, they may discourage employment creation and business investment by imposing a heavy burden on newly-created companies with little or no profits. The exclusion of new and small companies (assets up to 100 million yen) from the new Japanese enterprise tax will mitigate this risk. However, this deviates from the principle of benefit taxation - that every company using local public services should pay taxes, whether or not it makes profits - a principle supported by the Japanese government. It also introduces new tax distortions since small and large businesses will not be treated equally and the new tax may also favour sub-contracting as opposed to in-house provision (a problem that emerged in Hungary). Second, taxes on business assets and value-added may exacerbate enterprise failures during economic downturns by transferring the cyclical risk from local governments to companies. The business community has indeed opposed the reform, although it has been designed to be revenue-neutral. ${ }^{22}$

\section{Box 3. Problems with sub-national taxes on business value-added or assets in OECD countries}

Sub-national governments in several European countries rely on a business tax based on the value of the company's inputs, its assets or value-added. Such taxes have raised a number of concerns and some have been reduced recently.

In France, companies engaged in business activities are subject to a local business tax (Taxe professionnelle). The taxable base has long consisted of the company's rental value of equipment and buildings and its wage bill. This tax had been criticised for its adverse effect on employment creation and has been reformed. The taxable base has been narrowed substantially over the past decade, with the removal of the tax on the company payroll: until 1997, 18 per cent of wages paid were subject to this tax but this share was gradually reduced thereafter and abolished altogether in 2003. The loss of tax revenues for local governments has been offset by increased central government transfers. The taxable base now only consists of the rental value of commercial and industrial buildings and equipment. Early in 2004, President Chirac announced that the taxe professionnelle will soon be significantly revamped.

In Germany, the local business income tax (Gewerbesteuer) is a tax on a company's inputs, though the base is wider than the French taxe professionnelle. Originally, this tax was conceived as a value-added tax, with the tax base consisting of the income of all production factors. The tax base has, however, been gradually narrowed over the past decades. The payroll component was abolished in 1980 and since 1984 only 50 per cent of interest payments on longterm debt are taxable. The imputed value of buildings and equipment was also excluded in 1997 with the loss of revenues for the municipalities compensated by tax-sharing arrangements on the VAT. A reform is under discussion in the Commission for Reforming Municipal Finances set up by the Federal Government. One key issue is whether the local business tax should be more profit-oriented (an option preferred by businesses since it would better reflect their true income) or more "input-oriented" (preferred by municipalities since it would ensure more stable tax revenues).

In Hungary, the local business tax is by far the most important source of tax revenue for local government at over 70 per cent. It is levied at a locally-determined rate of up to 2 per cent on a base that resembles value-added (sales revenue, excluding VAT, plus interest income less the acquisition cost of goods sold, material cost and the cost of subcontractors). It is widely criticised for being biased by discretionary exemptions and for creating a bias in favour of subcontracting (as opposed to in-house provision). Until 2003, local governments could grant exemptions from the local business tax at their discretion, which could create a problem in localities where links between local business and local officials are strong. A high reliance on the local business tax also creates undue imbalances in the resources available for local public goods as proceeds tend to be highest in the richest regions. The Finance Ministry's initial plans for the 2004 budget envisaged changes to the local business tax but these were not included in the final budget submission.

22. Nippon Keidanren - the leading business group in Japan which is mainly composed of large companies recommended in September 2003 that the government reconsider the introduction of a value-added and an asset component in the prefectural enterprise tax. According to Keidanren, the new enterprise tax raises two concerns. First, it introduces a new distortion between large and small companies. Second, members fear that taxing assets could disrupt companies' efforts to strengthen their own capital. 
In Italy, a regional tax on productive activities (IRAP) was introduced in 1998 to replace a number of taxes, including the local income tax. The tax base includes profits, interest payments, labour costs and other components of valueadded. Depreciation allowances and intermediate inputs are not taxable. Although when introduced it was considered as a major step towards greater regional autonomy, there is concern about the effective degree of fiscal autonomy in poorer regions where the tax base is small and about the relatively high tax burden on the self-employed and small companies. Reforms are under consideration to replace the unpopular IRAP with another tax for the regions.

In Spain, as from 2003, businesses with a turnover of less than 1 million euro are exempted from the Impuesto sobre las Actividades Economicas (IAE). The central government has estimated that 93 per cent of businesses which were liable to pay this tax in 2002 would qualify for an exemption. This tax is based on fixed elements such as the surface area of the premises and electricity consumption (the number of employees criteria was abolished recently).

32. Revenue bases of local government taxes are unevenly distributed across regions, calling for extensive equalisation schemes if the ability to provide certain standards for local public services is to be achieved throughout the country. Tax bases for local taxes on businesses are highly concentrated in urban areas. Illustrative is the fact that tax revenues per capita in Tokyo are almost six times higher than in the poorest prefecture. ${ }^{23}$ Regional imbalances are slightly less pronounced for the inhabitant tax on individuals but remain high. On the other hand, revenues from the prefectural consumption tax (VAT) and property tax are much more evenly distributed. Proceeds from these two taxes are also relatively stable over the economic cycle - an important criterion when discussing optimal tax assignment across levels of government. It should, however, be kept in mind that local governments have no discretion in setting consumption tax rates or base and that giving local government discretionary powers may entail high compliance and administrative costs and create distortions in trade between jurisdictions.

\section{Taxing powers of local governments have not been used effectively}

33. Local governments have some flexibility in setting the rates and bases of several taxes but have so far only rarely used it, or in a surprising manner. As in most other OECD countries, several of the socalled local taxes are in fact tax-sharing arrangements. Bases and rates are set by the central government, which is also responsible for collecting them (e.g. the prefectural consumption tax or the local share of the personal income tax - the so-called local transfer tax of the personal income tax - introduced in FY 2004). Tax proceeds are redistributed across jurisdictions according to objective criteria. For instance, for the local transfer tax of the personal income tax, the number of residents is used. For the road and hydrocarbon taxes, the criterion is the length of roads. In some cases, uniform tax bases have been instrumental in limiting tax evasion and avoidance and/or in keeping collection and compliance costs relatively low (e.g. for the prefectural surcharge on the consumption tax). For a number of other taxes, however, the Local Tax Law allows some flexibility in setting rates below, or above, standard levels. In particular, local governments can decide on the rate of the prefectural and municipal inhabitant taxes on individuals and on corporations, of property taxes and of the enterprise tax. This flexibility has been enhanced by the removal of the ceiling on the municipal inhabitant tax on individuals in 1998 and of the maximum property tax rate in April 2004. Overall, Japanese local governments' discretionary taxing powers are higher than in Austria, Germany, Italy and, until recently, Belgium and Spain (Table 5). ${ }^{24}$

23. Differences in local tax rates contribute only little to the dispersion in actual tax revenues since discretionary powers are rather limited and, when used, variations across jurisdictions are small. For example, seven prefectures out of 47 applied rates above the standard level for the enterprise tax in FY 2004. For six of them, the actual rates were set at, or below, 5 per cent above the standard tax rate.

24. The definition of the standard tax rate in the Local Tax Law was amended in 2004. It was changed from "the tax rate that local governments should use in standard cases but are not required to use if a special fiscal need is recognised" to "the tax rate... if fiscal and other needs are recognised" (the term "special" 
Table 5. Sub-national government taxing powers in selected OECD countries ${ }^{1}$ 1995

\begin{tabular}{|c|c|c|c|c|}
\hline & \multicolumn{2}{|c|}{ Sub-national government taxes relative to: } & \multirow{2}{*}{$\begin{array}{c}\text { Discretion to set } \\
\text { Taxes }^{2}\end{array}$} & \multirow{2}{*}{$\begin{array}{l}\text { Summary indicator } \\
\text { of taxing powers }\end{array}$} \\
\hline & Total taxes & GDP & & \\
\hline Sweden & 32.6 & 15.5 & 100.0 & 15.5 \\
\hline Denmark & 31.3 & 15.5 & 95.1 & 14.7 \\
\hline Switzerland & 35.8 & 11.9 & 92.4 & 11.0 \\
\hline Finland & 21.8 & 9.8 & 89.0 & 8.7 \\
\hline Belgium & 27.9 & 12.4 & 57.9 & 7.2 \\
\hline Iceland & 20.4 & 6.4 & 100.0 & 6.4 \\
\hline Japan & 24.2 & 6.8 & 90.3 & 6.1 \\
\hline Spain & 13.3 & 4.4 & 66.6 & 2.9 \\
\hline New Zealand & 5.3 & 2.0 & 98.0 & 2.0 \\
\hline Germany & 29.0 & 11.1 & 12.8 & 1.4 \\
\hline Poland & 7.5 & 3.0 & 46.0 & 1.4 \\
\hline United Kingdom & 3.9 & 1.4 & 100.0 & 1.4 \\
\hline Netherlands & 2.7 & 1.1 & 100.0 & 1.1 \\
\hline Austria & 20.9 & 8.7 & 9.5 & 0.8 \\
\hline Portugal & 5.6 & 1.8 & 31.5 & 0.6 \\
\hline Czech Republic & 12.9 & 5.2 & 10.0 & 0.5 \\
\hline Hungary & 2.6 & 1.1 & 30.0 & 0.3 \\
\hline Norway & 19.7 & 7.9 & 3.3 & 0.3 \\
\hline Mexico & 3.3 & 0.6 & 11.2 & 0.1 \\
\hline
\end{tabular}

1. The countries are ranked in descending order according to the value of the summary indicator of taxing powers.

2 The figures show the percentage of their total taxes for which sub-national governments hold discretion over the tax rate, the tax base or both the tax rate and the tax base. A value of 100 designates full discretion.

3. The summary indicator is the product of the ratio of sub-national government taxes to GDP and the degree of discretion to set taxes. Thus, it measures sub-national government taxes with full discretion as a percentage of GDP.

Source: OECD, Taxing Powers of State and Local government, 1999 and Revenue Statistics 1965-2001, 2002.

34. Local government autonomy in setting rates has so far failed to promote tax competition and fiscal discipline. Despite the flexibility offered by the law, most local governments have applied standard rates for the inhabitant tax on individuals and the property tax (Table 6). More surprisingly, all prefectures but one, as well as many municipalities, apply a rate above the standard one for the inhabitant tax on corporations. These outcomes seem to conflict with the fiscal federalism literature and the situation in several other OECD countries. Since companies are more mobile than households or properties, one would expect enterprise taxes to be more subject to tax competition.

35. Several factors could play a role in explaining this apparent absence of tax competition for companies. First, local enterprise taxes and property taxes are deductible from the central government tax base. Thus, a cut in local tax would not be reflected pari passu in a lower tax burden on local businesses since it would be offset, at least partly, by higher central government taxes. Symmetrically, an increase in local tax rates would not correspondingly reduce the attractiveness of a region since it would be partly offset by lower central government taxes. This may explain the tendency to apply rates above standard levels. Second, conditions and subsidies attached to local bond issuance make it unattractive to cut taxes. Indeed, a local government that cut taxes would no longer be allowed to issue bonds to finance local public works (Mochida, 2001). Third, since central government support is to some extent discretionary (e.g. in the allocation of earmarked grants), local governments may fear that cutting taxes could result in lower support

was dropped and "other" was added). In principle, local governments now have more flexibility in setting tax rates. No concrete examples of "other needs" have, however, been provided by the central government, raising questions about the local governments' effective use of this new flexibility. 
- a mechanism identified in other OECD countries, including Korea and Norway. ${ }^{25}$ Fourth, there are various regional development policy packages that allow local governments to introduce specific tax rebates so as to attract businesses and compensate them for the decline in tax revenue through higher grants (LAT). In this context, local governments tend to apply for such packages rather than lower rates across the board.

36. Local government tax autonomy also includes the right to grant special rebates to the taxes prescribed by the Local Tax Law and to introduce new local taxes. Local governments can introduce a large variety of tax exemptions without getting approval or even informing the central government. There are numerous examples of local governments using special tax rebates for attracting businesses (usually in industrial parks), although the central government has repeatedly expressed some concerns. ${ }^{26}$ One obvious risk of this form of tax competition is to make the tax system overly complex and reduce its neutrality. The tax autonomy of local governments has been further enhanced by the 2000 Amended Local Taxation Act which enables them to introduce "supra-legal taxes" (i.e. taxes not stipulated in national laws) after consultation with the Ministry of Internal Affairs and Communications (MIC). ${ }^{27}$ Many sub-national governments, both prefectures and municipalities, have introduced new taxes, including some on nuclear or industrial waste, hotel stays, or fishing. A number of concerns have, however, been voiced, in particular: i) these taxes fail to discipline local authorities since they often fall on non-residents or can be shifted on to them (tax exporting); ii) revenues are in many cases low, while collection costs may be high; iii) opportunities to introduce such taxes are extremely limited in rural jurisdictions compared to metropolitan ones, thus contributing to increasing regional imbalances (Kitamura, 2002 and Doi, 2004).

25. According to Akai, Sato and Yamashita (2001), the allocation of the special LAT is also to some extent discretionary.

26. According to the Economic Planning Agency (1998), exemptions are usually made on the prefectural enterprise tax, real estate acquisition tax and property tax for a limited period of time, usually three years. Some participants to the Expert Committee of the Japan Investment Council claimed in 1997 that local governments use such tax rebates quite extensively and in a discretionary manner to attract companies. The MIC has notified prefectural governors on several occasions that "Tax exemption, unequal taxation and tax relief should be thoroughly examined and should not be overused".

27. The central government is legally required to approve proposals of local authorities to introduce new taxes, except when the new tax: a) results in extremely high tax rates; b) impedes the mobility of goods and capital across jurisdictions; c) conflicts with national economic policies. Since April 2004, cuts in rates for the so-called "supra-legal taxes" no longer need to be approved by the central government. 


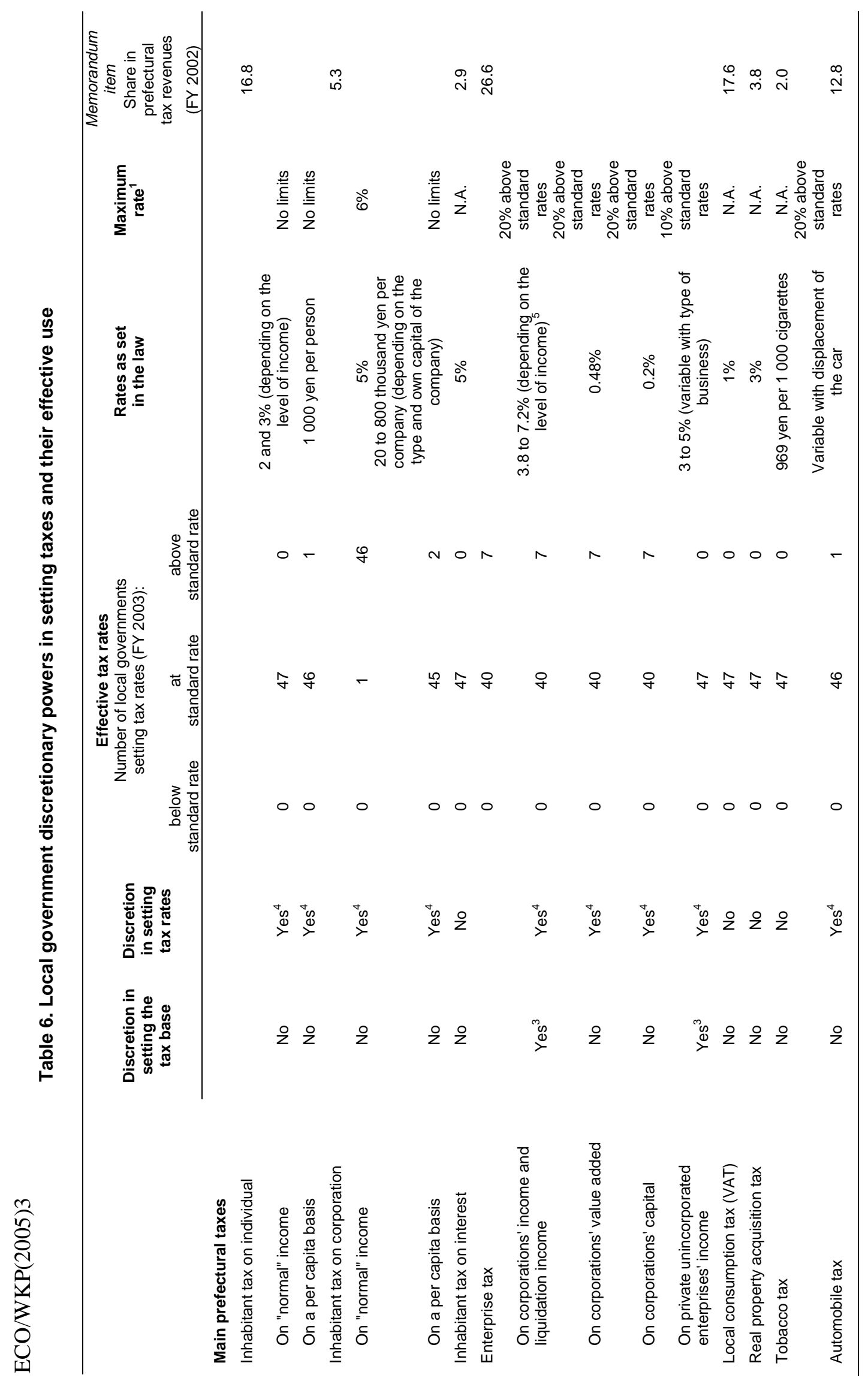




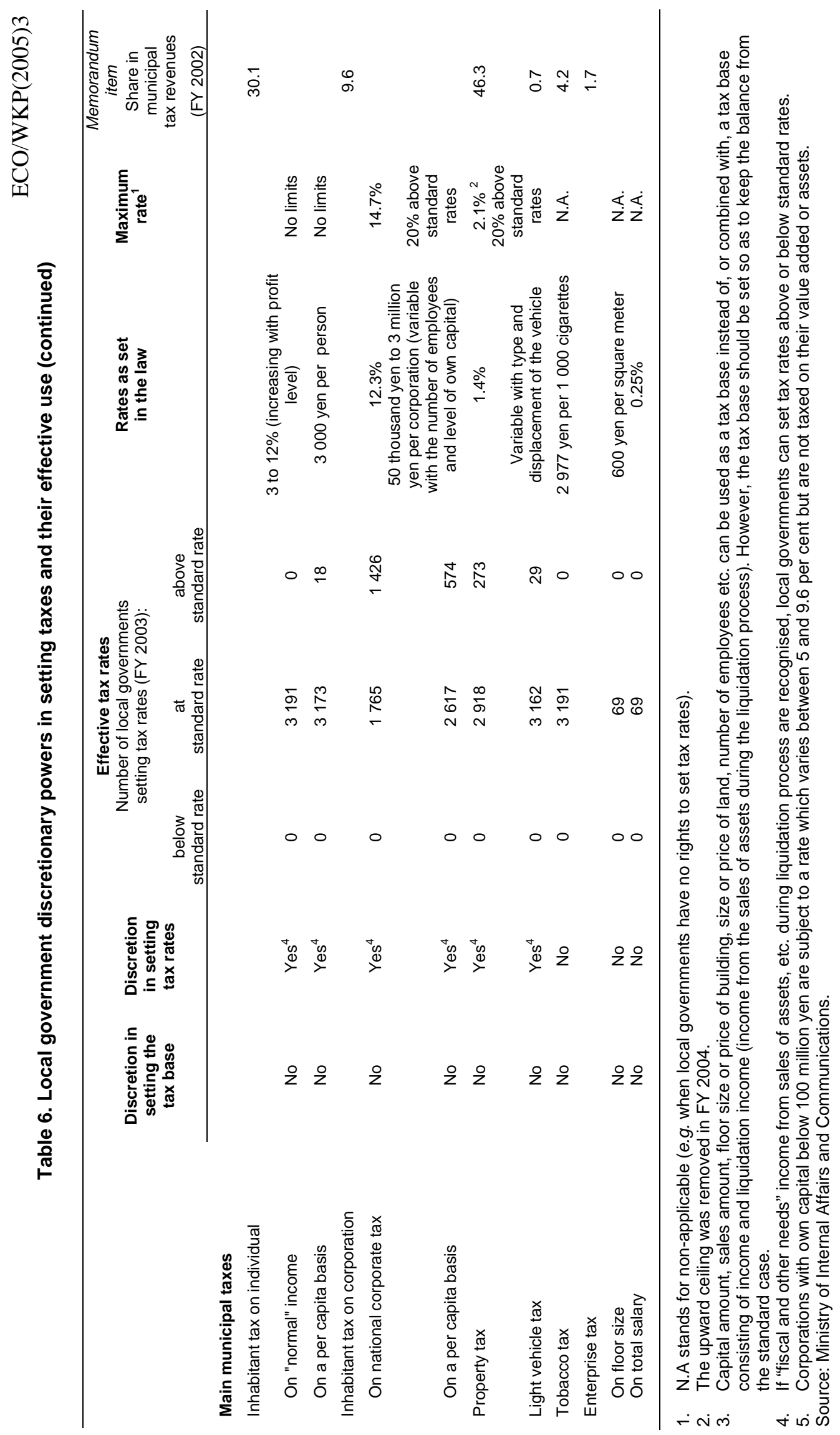




\section{Extensive equalisation schemes}

37. Equalisation schemes have made it possible to provide high quality public services throughout the country but they have absorbed an increasing amount of fiscal resources over the past decades and created significant adverse incentive effects, thus prompting calls for reforms. The need for equalisation in Japan stems mainly from the fact that the capacity to levy taxes differs across regions while local spending is partly of a redistributive nature (e.g. with a significant share of spending devoted to welfare benefits). The Local Allocation Tax (LAT) - a block grant - is the main equalisation scheme. Similar to those in Australia and the Nordic countries, it is based on criteria related to both financial capacities and needs/costs (Box 4 and Figure 6, Panel A). ${ }^{28}$ Earmarked grants have added to the already strong equalising power of the LAT, with low income/rural prefectures often receiving more than wealthier ones on a per capita basis (Panel B), in particular for public work projects (see above). Overall, some poor and/or remote jurisdictions end up having more financial resources than those available in the richest ones. The most striking examples are the prefectures of Kochi, Shimane and Tottori as against those of Aichi, Kanagawa and Osaka (Panel C).

\section{Box 4. Basic principles governing the Local Allocation Tax}

The Local Allocation Tax (LAT) system was introduced in 1954 and its basic framework has not changed much since. It serves two main functions: i) compensating for disparities in fiscal resources and needs; ii) filling the fiscal gap for local governments since their spending responsibilities significantly outpace their revenue-raising powers.

The demand for LAT transfers is derived from a formula based on the standard financial needs and revenues of each local authority. If needs exceed revenues, the jurisdiction is entitled to the LAT. If revenues exceed needs, the jurisdiction does not receive a LAT transfer, nor does it contribute directly to the equalisation scheme. In FY 2003, all prefectures except Tokyo and 96 per cent of the municipalities received it.

Standard fiscal needs of local authority i $\left(\mathrm{SFN}_{\mathrm{i}}\right)$ are calculated using the following formula:

$$
S F N_{i}=\sum_{k} F_{i k} * U_{i k} * M_{i k} \text { where: }
$$

$F_{i k}$ is a measurement unit specified for each public service $\mathrm{k}$ (e.g. the number of students, teachers and schools for education services; the size of the population for fire, sewage, garbage services as well as social assistance; length of roads for public construction, as well as local bond repayment costs);

$\mathrm{U}_{\mathrm{ik}}$ is a unit cost for service k. It is calculated by MIC using a "model" prefecture with a population of 1.7 million and a "model" municipality with 100000 inhabitants (Council of Local Authorities for International Relations, 2002). It is uniform across local governments.

$M_{i k}$ is a modification coefficient reflecting region-specific circumstances (such as population size, density, climate, etc). Since the mid-1980s, modification coefficients also account for bond repayment costs when certain kinds of "local independent projects" have been financed through local bonds (Akai et al. 2001 and Nakano, 2002).

Standard fiscal revenues of local government $\mathrm{i}\left(\mathrm{SFR} \mathrm{R}_{\mathrm{i}}\right)$ are calculated as the sum of local transfer taxes $\left(\mathrm{LTT}_{\mathrm{i}}\right)$, collected nationally but redistributed according to a prescribed formula, and 75 per cent of the revenues from local taxes that a local government would get if it applied standard tax rates $\left(\mathrm{t}_{\mathrm{j}}\right)$ on its estimated jth "potential" tax base $\mathrm{B}_{\mathrm{ij}}$.

$$
S F R_{i}=0.75 *\left(\sum_{j} B_{i j}^{*} t_{j}\right)+L T T_{i}
$$

The 0.75 factor is called a "reservation ratio". It is regarded as an allowance for the uncertainty of estimation and an instrument to retain incentives for increasing the local tax base.

28. In contrast, differences in expenditure needs are not taken into account in some other OECD countries, including Canada. 
The amount of money made available for the $L A T$ is a pre-specified share of revenues from five central government taxes (32 per cent of the personal income tax and of the liquor tax, 35.8 per cent of the corporation tax, 29.5 per cent of the consumption tax and 25 per cent of the tobacco tax in FY 2004).

Solving imbalances between the demand and the availability of funds for the LAT. There is no reason why the demand and availability for LAT transfers should match. The past decade of economic stagnation has reduced the resources available for the LAT while increasing demand. Adjustments have included: an increase in the share of national tax revenues (e.g. the share of the corporate tax increased from 32 to 35.8 per cent between FY 1998 and FY 2003); transfers from the central government to the LAT account and borrowing from the LAT Special Account (associated debt edged up to 50 trillion yen in FY 2003, about 10 per cent of GDP, up from 0.1 per cent in 1990).

Figure 6. The equalisation power of intergovernmental grants received by prefectures ${ }^{1}$ FY 2001 settlements

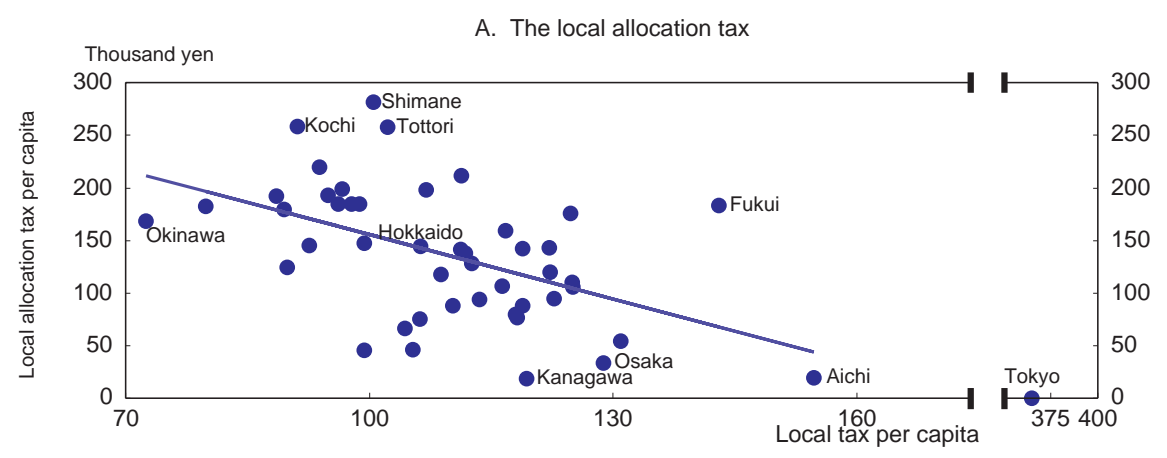

B. Earmarked grants

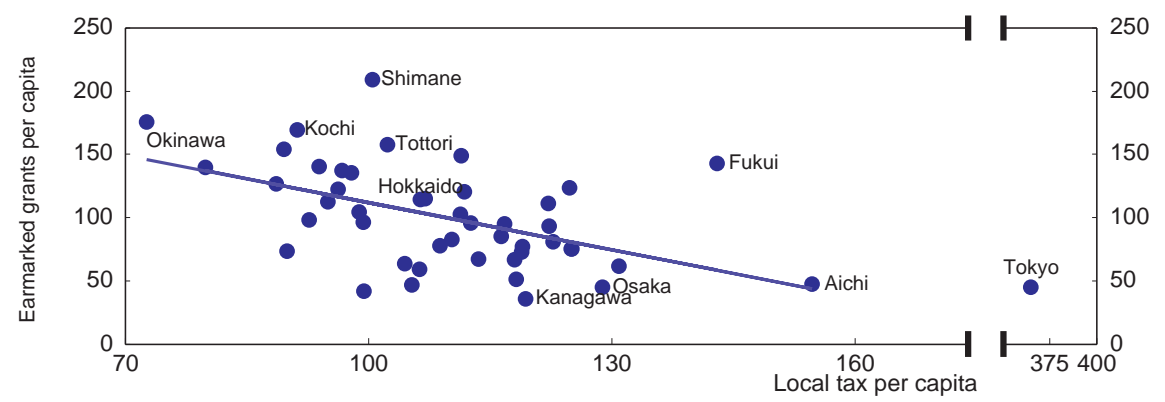

C. Total resources from grants and local taxes

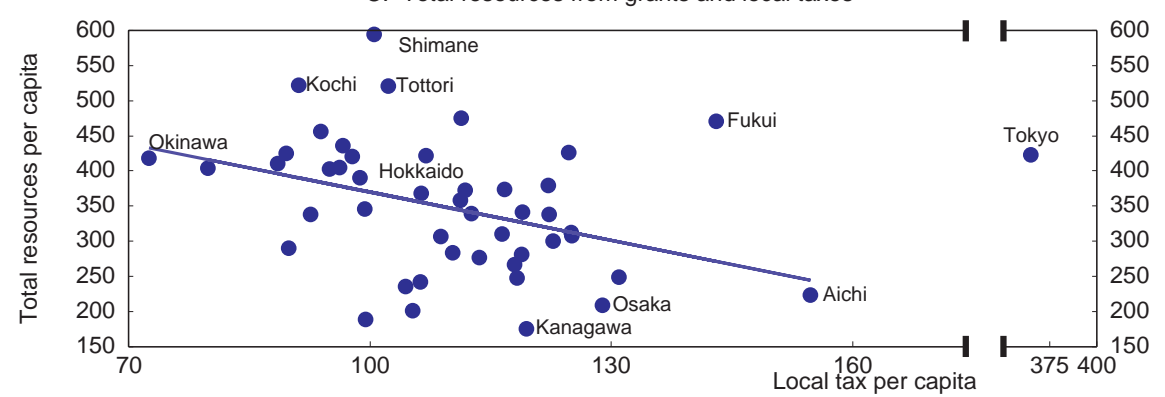

1. Regressions based on all 47 prefectures excluding Tokyo.

Source: Annual Statistics of Local Public Finance FY 2003 and 2000 Population Census, Ministry of Internal Affairs and Communications. 
38. Aside from intergovernmental grants, several factors have redistributed income across jurisdictions. First, central government income taxes take more from local governments with profitable companies and wealthier inhabitants. ${ }^{29}$ Second, the different financial conditions set for local government borrowing has also had some equalising effects (see below). On the other hand, social insurance schemes provide for less inter-regional redistribution than in many other OECD countries. In particular, national health insurance contributions vary by a factor of seven across jurisdictions for individuals with similar income, since they partly reflect past healthcare costs in the jurisdiction (Imai, 2002).

\section{The coverage and costs of fiscal equalisation schemes have increased over the past decades}

39. The fiscal cost of equalisation schemes has edged up in recent years while pre-transfer disparities between jurisdictions have narrowed and, by international standards, are relatively low. ${ }^{30}$ LAT transfers amounted to over 4 per cent of GDP in the early 2000s, up from 23/4 per cent in the mid-1980s, and most local governments are now eligible for this grant. Several factors have contributed to the upward pressures on the grant system. First, the LAT system has been asymmetric in adjusting for the business cycle. The money available for the LAT - a fixed share of central government tax revenues - increases during upswings. Cyclical tax windfalls have made it possible to upgrade minimum standards for local public services. During downturns, however, it has been difficult to cut back these transfers. The decline in funds available for the LAT has largely been compensated by borrowing from the LAT special account or by encouraging local governments to issue bonds whose future repayment costs are partly accounted for in the calculation of entitlements to the LAT, thus creating upward pressures on future LAT transfers. Second, several observers have argued that the vague definition of public services included in the standard fiscal needs formula, which the LAT equalises, has contributed to ballooning demand for transfers. Concerns have been expressed that the rapid expansion of standard fiscal needs over the past decades reflects efforts to stimulate the economy through specific incentives (in particular public works), as well as political lobbying, rather than equalisation needs. ${ }^{31}$ On the other hand, the LAT formula may fail to properly account for the specific situation of large urban centres since the number of residents is much lower than the number of users of local public services, in particular for inner city transport facilities. ${ }^{32}$

\section{Efficiency/equity trade-offs}

40. Similar to several other OECD countries, concerns have been raised that equalisation schemes may fail to promote public sector efficiency and, by creating poverty traps, hinder the catching-up process of poor jurisdictions. The LAT formula displays some attractive features which should limit moral hazard problems. By being based on "standard" tax revenues, it ensures that a change in local tax rates or the introduction of local tax rebates has no direct effect on the amount of equalisation grant received - a local government will not receive higher (lower) LAT if it cuts (increases) local tax rates. In addition, by excluding 25 per cent of local tax revenues - the so-called reservation ratio - from the equalisation scheme, it preserves some incentives to develop the local tax base. This is, however, considered to be too low to avoid poverty traps and convergence between richer and poorer regions could be slowed. ${ }^{33}$ Faced

29. As an illustration, 53 per cent of the national corporate income tax originated from Tokyo and Osaka prefectures in FY 2002 while these two urban centres accounted only for one-sixth of the country's entire population (National Tax Agency and Ministry of Internal Affairs and Communications).

30. See Mochida (1998) for a time perspective and Spiezia (2003) for cross-country comparisons.

31. See for instance Akai et al. (2001), DeWit (2002) and Doi (2004).

32. For Tokyo, the LAT formula is based on a daytime inflow population of 0.7 million inhabitants while 3.7 million people commute into Tokyo according to the Tokyo metropolitan government.

33. In its Annual Report on Japan's Economy and Public Finance, 2000-01, the Cabinet Office stated that “the present local administration and finance system is based on the national government's engagement in local 
with an implicit 75 per cent marginal tax rate on their revenues, local policymakers may have low incentives to implement growth-oriented policies even if they focus on maximising votes. ${ }^{34}$ In addition, measuring the "standard" local tax base is far from obvious since it would require correcting for the impact of all local policy actions (e.g. the quality of the infrastructure and administrative services or the elasticity of local tax bases to changes in tax rates).

41. The LAT may also weaken local government incentives to provide services in a cost-efficient manner for several reasons. Indeed, there was a diverging trend in spending between local governments which received LAT and those which did not: spending by non-LAT recipients declined in the second half of the 1990s while LAT recipients continued to increase spending (Cabinet Office, 2001). ${ }^{35}$ Among the features of the LAT system which create adverse incentive effects, several are worth mentioning, including:

- $\quad$ The LAT formula is not completely based on "standard fiscal needs" but includes some elements of actual spending (e.g. the length of roads or bridges and the number of schools). Thus, if a local government spends money on an unnecessary port or bridge construction project, it will receive more LAT (Doi, 2004). This contrasts with the practice in several other OECD countries where only those criteria that cannot be directly manipulated by local governments enter the formula. ${ }^{36}$

- A high unit cost of local public services can be compensated through higher grants (through modification coefficients), thus reducing the benefit of managerial efforts to contain costs. Additional LAT payments made to small jurisdictions to compensate for the higher costs associated with diseconomies of scale have been reduced but remain quite generous. ${ }^{37}$

- $\quad$ As grant entitlements are adjusted upward to finance most of the redemption costs of local bonds issued to finance public works, the LAT creates incentives to rely on debt financing instead of adjusting local taxes or spending levels. This also reflects the use of the LAT system to support national fiscal policy in recent years. In FY 2001, interest and redemption costs of local bonds accounted for 13.4 per cent of local governments' standard fiscal needs (Cabinet Office, 2001).

government spending and its massive fund transfers to local governments, working to discourage local governments from taking their own measures for regional development and prompting them to beg the national government for funding".

34. In Germany, similar concerns have arisen. See the 2002 OECD Economic Survey of Germany and Söllner (2001) for a theoretical analysis.

35. Although virtually all local governments receive a LAT transfer, Tokyo prefecture and several large municipalities do not. Because of their size, their share in total local public spending is large.

36. Similar to Japan, maintaining a balanced settlement pattern in the country by providing high quality public services even in remote areas has long been a priority in Norway (see the 2002 OECD Economic Survey of Norway). The equalisation scheme does take into account special topographic factors (in particular indexes for remoteness or population density) but does not include actual infrastructure endowments.

37. Recent changes have reduced the generosity of the system for small municipalities. First, the special treatment of municipalities with a population below 4 thousand inhabitants was abolished. Second, the sample used to calculate modification coefficients for local government size has been narrowed from all local governments to the most efficient two-thirds. To further lessen the amalgamation penalty, the "grace period" before entitlements to the LAT are recalculated has been extended: entitlements are maintained during the first five years and are reduced only gradually between the sixth and tenth years following the amalgamation. 
- The risk-sharing arrangement created within the LAT - the so-called special LAT which accounts for 6 per cent of total LAT payments and which is allocated to jurisdictions suffering from special factors such as natural disasters - has been used partly for redistributive purposes or to bail out jurisdictions facing financial difficulties (Akai et al. 2004).

\section{The "Trinity Reform"}

42. The government launched in FY 2002 an ambitious reform of the three main components of local government financial resources - earmarked grants, local taxes and the local allocation tax - the so-called "Trinity Reform". Although details are still under discussion, the general framework announced in November 2004 includes the following elements:

- A cut in earmarked grants to local governments by around 4 trillion yen over the period FY 2004-2006 (i.e. about 0.8 per cent of GDP). The budget for FY 2004 embodies a 1 trillion yen cut, of which 0.45 trillion yen are grants earmarked to public works. The remainder falls mainly on compulsory education and childcare which are still subject to rather strict regulations and standards set by the central government. ${ }^{38}$ For the years 2005 and 2006, based on a Cabinet decision, the central government has asked local governments to submit proposals on which earmarked grants could be cut (for an overall amount of 3 trillion yen). After intensive discussions, groups of local government leaders proposed to the prime minister a 9 trillion yen cut in earmarked grants (among which 3.2 trillion yen should be implemented over the years 2005 and 2006 and the rest during the period 2007 to 2009), thus surpassing the central government's target. ${ }^{39}$ However, this plan raised strong opposition from many of the central government ministries as well as ruling party members in the national Diet, and the debate between relevant parties was continuing as of the end of October.

- A streamlining of the Local Allocation Tax. Although the details of the changes in the LAT formula have not yet been announced, the FY 2004 budget incorporated a 1.2 trillion yen cut, which fell mainly on infrastructure spending.

- A transfer in tax resources from the central to local governments of about 3 trillion yen. The FY 2004 budget incorporated a 0.4 trillion yen transfer of national personal income tax revenues from the central to local governments. The allocation across local governments was based on population data. It should be noted that this tax-sharing arrangement is not accompanied by a transfer of taxing powers since local governments are not entitled to set either the rates or the base of the national personal income tax. In June 2004, the government announced that it will cut the national personal income tax and increase local governments' reliance on the individual inhabitant tax by FY 2006. In the event, standard rates for the individual inhabitant tax on income will be flattened so as to strengthen the benefit principle (local taxes should reflect more the use of local public services than residents' ability to pay) and avoid a distribution of tax resources across local governments that would be too uneven.

38. The budget for 2004 embodies a 0.2 trillion yen increase in special local grants, which are not earmarked, to compensate for the cut in earmarked subsidies on primary education.

39. The proposal to cut 3.2 trillion yen in 2005 and 2006 requires the abolition of 45 subsidies in the social security area, 33 in public works, 15 in education and 55 in other areas. 


\section{Securing fiscal discipline in a decentralised setting}

43. Local debt has soared rapidly since the early 1990s, reaching about 40 per cent of GDP in FY 2003, up from 15 per cent in 1991 (Figure 7). While local government borrowing has largely been used to finance infrastructure projects, there is doubt as to whether this has helped to boost the potential growth of the economy since the rate of return of local public investment has been low (see above). Local governments' ability to repay their debts is thus questionable, creating the risk of adding to the bad loan problem that Japan has faced over the past decade. ${ }^{40}$

Figure 7. Trends in local government debt

Stocks at end of fiscal year

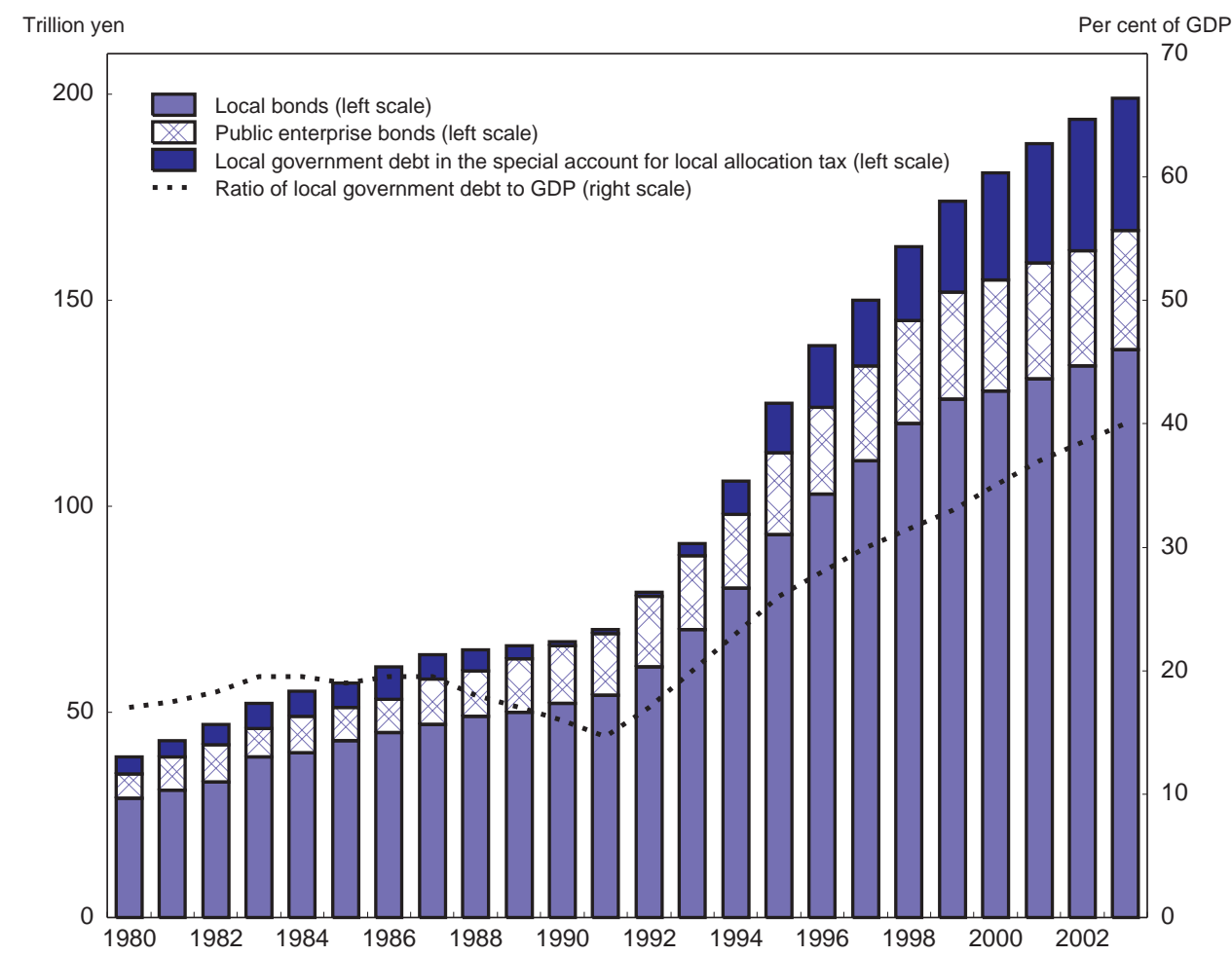

Source: Ministry of Internal Affairs and Communications.

44. Contingent liabilities at the local government level also seem to be high. Although reliable estimates are difficult to produce, the upward revision to general government debt by about 10 per cent of GDP in 2002 - when the liabilities held by the local government special account for sewage were recognised - suggests that contingent liabilities may turn out to be sizeable. One important risk originates from the financial difficulties currently faced by many local public corporations jointly owned with the

40. Doi (2002) estimates the risk of local government insolvency under several scenarios and, as a consequence, the default risk for public institutions holding local government bonds. Assuming that local governments' primary financial balance will remain at the average level of FY 1997-2000, 64 per cent of the outstanding loans from the Fiscal Investment and Loan Programme (FILP) to local governments and 62 per cent of those from the Japan Finance Corporation for Municipal Enterprises would be defaulted. It should, however, be kept in mind that the assumption on the local government financial balance is rather pessimistic in the light of recent economic developments. 
private sector (the so-called "third-sector"). According to the MIC, there were over 10 thousand local public corporations in March 2003 and about 56 per cent of these were jointly established with the private sector. Many of these third-sector corporations appear to be subject to insufficient public monitoring. Unless the government's share of equity is more than 25 per cent, the companies are subject to neither monitoring by the local assemblies nor to review by the audit committee. Residents, though, may request disclosure. The lack of strict rules for risk sharing in the contracts leads the private sector to expect an implicit guarantee, thereby weakening incentives to minimise costs. A report of a study group in the Ministry of Finance (2001) suggested a positive correlation between the amount of debt held by companies and the share of public funds in their capital. In addition to the third sector, the government introduced the so-called "Private Finance Initiative" in the late 1990s for specific projects and with clearer rules for the sharing of risk across public and private participants. It is, however, still too early to judge whether potential adverse incentives have been redressed (Akai, 2003a) and estimates of implicit liabilities are still lacking.

45. Pressures on future public spending stemming from the rapid ageing of the Japanese population further reinforce fiscal sustainability concerns at the local level. The projected increase in public spending on health and nursing care for the elderly will largely fall on local governments. In the shorter run, the number of local public employees retiring is expected to reach a peak between 2007 and 2009. The Cabinet Office (2001) estimated that local government implicit liabilities associated with pensions and retirement allowances amount to 70 trillion yen (14 per cent of GDP). Although some local governments have accumulated reserves to finance these obligations, they are likely to be insufficient.

\section{Administrative controls and fiscal rules have failed to restrain local government debt}

46. While requirements for local public services imposed by the central government and the design of the grant and tax system have created the conditions for an increase in local government debt, administrative controls on local bonds and fiscal rules have so far failed to provide counteracting pressures. Local government access to the bond market is, in principle, subject to a rather strict system of administrative controls by the central government. National laws prescribe which expenditures can be financed by local government bonds and dictate a number of fiscal rules to be respected if a local government envisages issuing local bonds (Box 5). In addition to these rules, any individual prefecture and large city must obtain permission from the MIC before issuing bonds, whereas small municipalities have to get approval from the prefectures. 


\section{Box 5. Fiscal rules imposed on local governments and regulations for issuing bonds}

The Local Finance Law states that bonds can only be used to finance: i) expenditures on local public corporations engaged in transportation, gas, water and others; ii) investment in, and lending to, organisations (including third-sector companies) involved in areas of public interest (e.g. local roads, airports, sports, etc); iii) loan refinancing; iv) expenditure on disaster recovery; and v) expenditure on construction of public facilities (such as schools and roads) and purchase of land for building public facilities. In addition, the central government has "exceptionally" allowed the issuance of bonds in a number of specific situations. Over the period FY 1990-2001, local governments issued "temporary bonds for public works" (15 trillion yen), "tax cut supplement bonds" ( 7 trillion yen), "revenue decrease supplement bonds" (6 trillion yen), "retirement benefit bonds" and "amalgamation bonds".

The Local Autonomy Law and the Local Finance Law - both national laws - also define a number of conditions a local government should comply with in order to be allowed to issue bonds. The main ones are:

- "Ad hoc financing" (the so-called "net revenue") should not exceed 5 and 20 per cent, respectively, for prefectures and municipalities of general-purpose resources (i.e. mainly ordinary taxes, LAT and the Local Transfer Tax). The net revenue is defined by subtracting expenditure from the sum of local taxes, LAT, earmarked grants, fees and charges, and local bond issues. ${ }^{1}$

- The average ratio of debt repayment costs (only principal and excluding those financed through the Local Allocation Tax) to general-purpose resources over the past three fiscal years should be below 20 per cent.

- Its ratio of tax collection to estimated tax revenues in the year falls to less than 90 per cent.

In addition, a local government setting tax rates below standard rates set by the central government is not allowed to issue bonds to finance public works.

If local governments do not comply with these rules, they can, under certain conditions, continue to issue bonds. For instance, a municipality running a so-called net revenue exceeding 20 per cent of its general-purpose resources can still issue bonds if it has introduced a "financial rehabilitation plan" approved by the MIC. This entails measures to increase revenues by setting tax rates above standard tax rates and measures to cut spending by reducing the number of government employees and their compensation and by cutting investment. When introducing a financial rehabilitation plan, the local government receives extra financial support from the central government, including subsidised bonds and special LAT. The most recent financial rehabilitation plan was approved for the town of Akaike in 1991 and was completed in 2000. Currently, no local government is under a financial rehabilitation plan.

1. If bond issues were used only to finance investment, this "net revenue" rule would be broadly similar to a rule on the operating balance. However, bonds have been used extensively to finance local government deficits. Examples of ad hoc financing used by local governments include: withdrawals from various funds (Osaka prefecture) and advance spending from the next year's budget (Chiba prefecture). 
47. Despite a rapid increase in local debt, the existing fiscal rule on debt servicing costs has not yet become binding since it deducts bond repayment costs, which are financed through the LAT, from the total amount of local government servicing costs. According to the type of bond and/or the fiscal capacity of local government, from 30 to 100 per cent of the repayment costs are to be financed through higher grant entitlements (Table 7). ${ }^{41}$ Reflecting this very generous system, the amount of local debt service which is not accounted for in the fiscal rule is significant. At the aggregate level, local government debt servicing costs (including interest payments and principal costs covered by the LAT) stood at about 27 per cent of local government general-purpose revenues in the budget for FY 2004. This means that if the broader definition of the rule were to be implemented, a large number of local governments would probably overshoot the 20 per cent ceiling.

48. The rule on local governments' financial balance has also remained extremely lenient. Local governments in many OECD countries (including Denmark, France, Korea, and Spain) are now subject to a balanced budget rule, either for the total budget or on an operating basis (Joumard and Kongsrud, 2003). In contrast, the "net revenue" rule in Japan obliges municipalities to keep their reliance on ad hoc financing sources below 20 per cent of their general-purpose revenues ( 5 per cent for prefectures). The grant system has contributed to further soften this rule. First, the longstanding increase in block/equalisation grants has been reflected in higher general-purpose resources for local governments, thus raising their borrowing limit. Second, the rule is so designed that increases in local government debt make it possible for local governments to run into more debt in the future since bond repayment costs are taken into account when calculating their grant entitlements, and, hence their general-purpose resources.

49. Central government control not only applies to the amount of bond issuance but also, to a large extent, specifies bond subscribers. When permission to issue bonds is granted, the MIC decides how many of the bonds will be bought by public bodies (Doi, 2002) - mainly under the umbrella of the Fiscal Investment and Loan Programme (FILP). In FY 2002, almost 60 per cent of local bond issues were purchased by public institutions (Table 8 ). The system is largely designed to ensure that adequate funds flow into smaller or poorer local governments so as to balance fiscal resources across prefectures (Hayashi, 2004). ${ }^{42}$ Empirical evidence on the composition of lenders by prefecture suggests that in distributing FILP funds, central government gives priority to local governments facing financial difficulties. Since conditions attached to public funds are more favourable (with both lower interest rates and longer maturity), local governments may be shielded from pressure to redress their financial situation. Evidence from Doi (2002) indeed suggests that a prefecture which relied heavily on FILP funds in the past tends to remain heavily dependent on such funds. ${ }^{43}$

41. Mochida (2004) estimated that the central government finances more than one-third of local government outstanding bonds. Higo and Nakagawa (2001) have produced similar estimations for FY 1999.

42. See, for instance, Risk and Investment (2002), which notes that "there are growing doubts that the (central) government will be able to fully support the future ability of local governments to fulfil their debt services obligations". It thus introduced new rating criteria for local government bonds. Doi (2001) found a negative correlation between the share of public finance lending and the effective interest rate of local bonds, which implies that a tacit regional income redistribution is carried out by the local bond approval system.

43. Even after the reform of the FILP in 2001, postal savings and the postal insurance fund have continued lending money directly to financially weak local governments. Lending conditions are not subject to bilateral negotiations between lenders and borrowers. Instead, uniform standards are set by the central government. On this issue, see also Doi and Hoshi (2002). The government plan to privatise postal services and related businesses in FY 2007 is, however, likely to significantly affect local government financing conditions (PHP, 2004). 
ECO/WKP(2005)3

Table 7. Sharing the repayment costs of selected local government bonds FY 2001, billion yen

\begin{tabular}{|c|c|c|c|}
\hline & $\begin{array}{l}\text { Outstanding } \\
\text { local bonds }\end{array}$ & $\begin{array}{c}\text { Share of } \\
\text { repayment costs } \\
\text { accounted for in } \\
\text { the LAT formula } \\
\text { Per cent }\end{array}$ & $\begin{array}{l}\text { Estimated central } \\
\text { government } \\
\text { repayment costs }\end{array}$ \\
\hline \multicolumn{4}{|l|}{ Name of local bonds } \\
\hline General public works & 25452 & - & 11068 \\
\hline Temporary public works & 13835 & 80 & 11068 \\
\hline General independent public works & 52487 & - & 10249 \\
\hline General regional development & 10871 & $30-55$ & 3261 \\
\hline Temporary local road building & 16071 & $30-55$ & 4821 \\
\hline Temporary river related projects & 2147 & $30-55$ & 644 \\
\hline Temporary economic package & 2051 & 45 & 923 \\
\hline Public housing construction & 5150 & - & 0 \\
\hline Compulsory education facilities building & 5031 & $30-70,100$ & 1509 \\
\hline Advance purchase of land for public facilities & 2226 & interest only & 0 \\
\hline Natural disaster recovery & 1304 & - & 1072 \\
\hline Tokyo metropolitan area development & 1178 & - & 0 \\
\hline General waste disposal & 4702 & $50 / 100$ & 2351 \\
\hline $\begin{array}{l}\text { Depopulated area aid } \\
\text { National budget related and government affiliated }\end{array}$ & 2418 & 70 & 1693 \\
\hline $\begin{array}{l}\text { organisation loan } \\
\text { Financial support to fill local government financing }\end{array}$ & 1203 & - & 0 \\
\hline gap & 3109 & 80 & 2488 \\
\hline Revenue decrease supplement $(1982,1993,1997)$ & 5302 & $75-80$ & 4242 \\
\hline Temporary special fiscal & 2689 & 100 & 2689 \\
\hline Tax cut supplement & 6227 & 100 & 6227 \\
\hline $\begin{array}{l}\text { Temporary tax cut supplement } \\
\text { Temporary fiscal aid }\end{array}$ & $\begin{array}{l}1265 \\
1227\end{array}$ & $\begin{array}{r}100 \\
80\end{array}$ & $\begin{array}{r}1265 \\
982\end{array}$ \\
\hline \multicolumn{4}{|l|}{ Memorandum item: } \\
\hline $\begin{array}{l}\text { Total outstanding local bonds } \\
\text { (excluding borrowing from LAT Special Account) }\end{array}$ & 130954 & & 47403 \\
\hline
\end{tabular}


Table 8. Purchases of local government bonds by type of institution

\begin{tabular}{lrrrr}
\hline (billion yen) & FY 1990 & Per cent & FY 2002 & Per cent \\
\hline Public funds total & 4069.2 & 64.9 & 7412.8 & 55.7 \\
$\quad$ Government funds & 2894.7 & 46.2 & 6160.6 & 46.3 \\
$\quad$ NTT special fund & 877.8 & 14.0 & 746.9 & 5.6 \\
$\quad$ Japan Finance Corporation for Municipal Enterprises Funds & 296.8 & 4.7 & 505.2 & 3.8 \\
Private funds $_{\text {Public offerings }}{ }^{1}$ & 2184.8 & 34.9 & 5835.5 & 43.8 \\
$\quad$ Mutual relief of local government employees & 483.8 & 7.7 & 1919.1 & 14.4 \\
$\quad$ Banks and others & 156.0 & 2.5 & 170.5 & 1.3 \\
Total & 1545.0 & 24.7 & 3745.9 & 28.1 \\
\hline
\end{tabular}

1. A significant part of public offerings is purchased by public institutions, including postal savings (285.8 billion yen in FY 2002) and postal life insurance (85 billion yen in FY 2002).

Source: Ministry of Internal Affairs and Communications.

\section{Financial markets have not enhanced the fiscal discipline of local governments}

50. Although the private sector has underwritten an increasing share of local government bonds, market mechanisms have not been playing a major role in enhancing local government fiscal discipline. In several OECD countries, particularly Canada and the United States, credit ratings in bond markets seem to act as a disciplining factor (Poterba and Reuben, 1997). Financial markets also play a part in disciplining sub-national authorities in countries like the Czech Republic, Hungary, Finland and New Zealand, as subnational debt is not guaranteed by the central government. In Japan, several factors have limited the disciplining role of financial markets:

- $\quad$ Local government debt is implicitly guaranteed by the central government. The permission from the MIC to issue bonds is often interpreted as a de facto central government guarantee on those bonds (Ishii and Wada, 1998, Hayashi, 2004). In addition, under the existing approval system for local bonds, the central government guarantees financial resources for the repayment costs of approved bonds through the LAT system.

- $\quad$ Private-sector funds cover only about 40 per cent of total local bond issues - private banks buy 30 per cent and the remaining 10 per cent are offered directly on the market. In this context, public institutions play a dominant role in setting the conditions for publicly-advertised bonds as well as for bank lending. For bonds underwritten by private banks and other financial institutions, the issuing conditions are, in principle, established through bilateral negotiations between individual local governments and lenders. In practice, however, lending terms have followed those agreed upon for other publicly-advertised bonds (partly subscribed by public bodies).

- In deciding whether to buy local government bonds, private banks often take into account a number of factors aside from local government creditworthiness, including the ability to secure a significant amount of public funds as deposits and the possibility to legally acquire valuable information such as the value of public works orders that local governments place with certain companies (Doi, 2004). Banks have also been keen to finance local governments in a period when the demand for loans from private companies remained sluggish. Recent signs of a 
recovery in private domestic demand may, however, reduce their ability and eagerness to buy local government bonds. ${ }^{44}$

51. Recent reform initiatives could contribute to enhancing the role of financial markets in disciplining local governments. Reflecting the widening gap in the secondary market prices, the central government has allowed the Tokyo metropolitan government to issue bonds under different conditions (in particular lower interest rates) than those applying to publicly-advertised bonds issued by other local governments since April 2002. By acknowledging differences in the financial situations of local governments and in the liquidity of local bonds, this new approach - called the 2-Table-approach - could have served to enhance market principles. However, although interest rates on local bonds initially differed, the gap gradually narrowed and completely vanished between September 2002 and March 2004 . Doi (2004) attributes this convergence to statements by officials from the MIC denying the differences in creditworthiness of local bonds, attributing the differences in market prices in the secondary market only to liquidity factors, and restating the implicit central government guarantee on all local bonds. ${ }^{45}$ Despite this price convergence, there is a possibility that the gap in secondary market prices may widen again and that uniform issuance conditions would become difficult to maintain in the future. To avoid a sudden increase in financing costs for local governments facing financial difficulties, the central government allowed local governments other than Tokyo to jointly issue publicly-advertised bonds in April 2003. This approach improves liquidity of local bonds. It may, however, weaken individual local governments' incentives to improve their creditworthiness once they have joined the group. ${ }^{46}$

52. Another major reform announced by the central government is the abolition of the approval system for local bonds in FY 2006. Under the new system, local governments should consult with the MIC before issuing bonds. If the MIC disagrees, they can still issue bonds but repayment costs will not be accounted for in the LAT formula. This system could contribute to enhancing the role of financial markets in disciplining local government fiscal behaviour since the previous approval system has often been perceived as an implicit guarantee by many investors and local government officials. Local bonds with an agreement will, however, continue to be guaranteed by the central government.

44. According to Norinchukin Research Institute (2003), city banks and regional banks have been reducing their holding of local bonds in recent years while those of mutual benefit associations (especially those in the agricultural sector) have increased. The Japan Credit Rating Agency argues that after the partial introduction of the pay-off deposit insurance in April 2002, some local governments have withdrawn their deposits from financial institutions in difficulty, leading to a deterioration in the relationship between local governments and local financial institutions (including bond underwriting).

45. There are several analyses of the determinants of local bond prices on the secondary market. Using December 2001 data, Mochida (2004) found that the main factor behind the price gap was the difference in the degree of liquidity, but the influence of creditworthiness could not be totally denied. Norinchukin Research Institute (2002) notes that the interest rate spreads across local bonds widened markedly since the latter half of 2001 and that the influence of creditworthiness became clearer between 2000 and 2002.

46. Issuing local governments agreed to contribute to a fund that serves to ensure the repayment of the debt in the case of a natural disaster or a crisis in a local financial institution. This introduces a moral hazard problem, leading to weaker local authorities borrowing more than they would without the pooling system (Robaschik and Yoshino, 2004). 


\section{Agenda for further reform}

53. Heightened concerns about fiscal sustainability and the demand for better tailored local public services are making it necessary to revamp fiscal relations across levels of government. The Japanese authorities have recently implemented some reforms and are planning additional measures that are steps in the right direction. To deliver their full benefits, though, they should be accompanied by other initiatives. Recommendations for further reform are discussed below and Box 6 provides a synopsis.

\section{Box 6. Recommendations for improving fiscal relations across levels of government}

Improve local governments' ability and incentives to manage local public services efficiently

- Pursue and diversify measures to enable local governments to exploit scale economies. Co-operative arrangements across local governments should be encouraged. This would require reforming further the grant (LAT) system and possibly providing legal and accounting assistance to local governments.

- $\quad$ Reassess the need for strict standards and regulations imposed on the delivery of local public services. For those sectors where national objectives are of concern, rely on norms defined in terms of outcomes/outputs rather than on regulations on inputs and operational management. Standards on local government employee salaries should also be reviewed, allowing regional variations in wage levels.

- $\quad$ Clarify the actual norms imposed by the central government and the responsibilities of both prefectures and municipalities so as to allow local governments to exercise their autonomy and become more accountable towards local citizens.

- Improve transparency in local public procurement contracts, with clear dispute and settlement facilities.

Contain the costs and adverse effects of the grant system

- Reliance on earmarked grants should be reduced, the objectives reviewed so as to avoid potential conflicts and old grant programmes reviewed in the light of new objectives and financial constraints.

- $\quad$ End the reliance of equalisation grants (LAT) on volatile national revenues for funding in order to reduce their asymmetrical behaviour over the business cycle.

- Reassess the coverage of local public services to be included in equalisation schemes. Adjust the grant formula so as to reflect objective needs (e.g. resulting from topographic or socio-economic circumstances rather than from actual spending or infrastructure endowments).

- Remove the incentives embodied in the grant system that favour debt financing by ending the practice of including debt repayment costs in the calculation of grant entitlements for new bond issues.

- Limit discretionary elements (including the special LAT), which could create moral hazard problems, and improve the transparency of the adjustment factors accounted for in the LAT formula.

Increase local government tax autonomy while keeping the tax system as simple and neutral as possible

- Barriers to the effective use of existing powers to set local tax rates should be removed. In particular, central government permission for local bond issuance should no longer be made conditional on local governments' setting local tax rates at, or above, the standard levels defined by the central government. Local business and property taxes should no longer be deductible from central government tax bases.

- In raising local government tax revenues, priority should be given to base-broadening measures for existing taxes (in particular the personal income tax) as opposed to the introduction of new taxes. Local governments' right to introduce specific tax rebates to attract companies should be limited since it does not promote healthy tax competition. Raising property values for tax purpose closer to the market value would also be desirable. 
- If new tax resources are to be transferred to local governments, give priority to taxes which are less volatile, have no significant adverse effects on the potential growth rate and cannot be easily exported.

Harden fiscal rules and strengthen the role of financial markets to ensure fiscal discipline

- The "net revenue" rule should be transformed into a balanced operating budget rule while the coverage of the rule on debt servicing costs should be broadened to include all bonds and interest payments.

- To enhance local government incentives to comply with the rules, sanction mechanisms may be needed. At a minimum, the existing financial support for local governments facing financial difficulties (e.g. subsidies for bond issues, access to preferential borrowing conditions) should be eliminated so as to avoid moral hazard problems.

- $\quad$ Fiscal rules should be re-designed so as to prevent new debt from raising grant entitlements and thus enabling local governments to accumulate more debt.

- $\quad$ Financial markets should be given a role in disciplining local government fiscal behaviour. This will require reducing further the share of local bond issues underwritten by public bodies, by removing central government de facto guarantees (grant entitlements being adjusted to cover bond repayment costs) and by stating consistently that the central government will not act as a lender of last resort.

- Improve transparency of local government contingent liabilities (including the unfunded liabilities stemming from retirement allowances and pension commitments for local public employees, deficits and liabilities of local public enterprises and public-private partnerships).

- Clarify risk-sharing arrangements when local public enterprises or third-sector enterprises are providing public services on the behalf of one or several local governments.

\section{Improve local governments' ability and incentives to manage local public services efficiently}

54. There is ample scope to increase the cost effectiveness of local public spending by giving local governments more leeway in carrying out responsibilities that have been assigned to them and by strengthening incentives to exploit scale economies. Reform of the grant system would be instrumental in these two respects.

55. Policy measures to support amalgamation of small municipalities have been commendable and should be continued. Despite recent adjustments, the grant (LAT) system is still overly generous for small municipalities and needs to be further amended to promote efficiency-enhancing mergers. The reform of the LAT system should also remove the existing barriers to co-operative arrangements. In particular, the grant formula should no longer take into account the number of providers in receiving jurisdictions.

56. Streamlining regulations imposed on local governments and making them more transparent is desirable. While some regulations may be needed to ensure that local governments behave in conformity with national objectives, care should be taken that they do not impair local government ability to manage effectively the responsibilities assigned to them. Reliance on regulations formulated in terms of inputs and procedures (e.g. floor size of schools) should be minimised.

\section{Reduce reliance on earmarked grants}

57. The low cost-effectiveness of local spending programmes financed through earmarked grants calls for a profound reform in this area. Problems have mainly arisen from the number of objectives (which in some cases are not internally consistent) attached to earmarked grants, the rigidities in the allocation process combined with the lack of a proper assessment of their benefits, as well as from the limits and adverse incentives they create on local government efforts to improve cost-effectiveness. While the use of 
earmarked grants to account for clear spillover effects makes sense, the central government should aim at changing the conditionality from pure input/procedure elements to target outcomes and quality of services provided by local governments. This would enable local governments to develop more cost-effective managerial approaches. In the education sector for instance, grants should no longer be made conditional on local governments complying with extremely detailed standards for floor size, availability of rooms, equipment and so on, but rather on school performance.

58. The use of earmarked grants for economic stabilisation and redistributive objectives should be reconsidered, in particular for public works. This would entail reforming further the budget process so as to trigger the reallocation of public funds across ministries - which has proved to be overly rigid in the past - within the general government expenditure cap. In addition, the allocation of funds should be based more systematically on ex ante cost-benefit analysis, relying as much as possible on independent evaluations. This would likely entail a cut in local public works and a change in the allocation of funds across regions (away from poor and rural areas to urban ones) and sectors. Achieving redistribution objectives through direct income transfers to individuals or block grants are likely to be more cost-effective than through local public works. Efforts to reduce the costs of developing local infrastructure should be made by widening the coverage of competitive bidding in public works, reviewing policies aimed at supporting small and medium-sized enterprises (SMEs) through tendering arrangements and introducing a common nation-wide framework for public procurement with clear dispute and settlement facilities (see the 2003 OECD Economic Survey of Japan).

\section{Reforming the fiscal equalisation scheme to mitigate its fiscal costs and efficiency/equity trade-offs}

59. The longstanding upward drift in the coverage and costs of the main equalisation scheme (LAT) needs to be halted. Recognising that the quality of public services is now high in most parts of the country, there is a need to reassess the coverage and generosity of the LAT against other major national policy objectives, in particular the need to restore fiscal sustainability. The coverage of "standard fiscal needs", which enter in the calculation of grant entitlements, should be reviewed systematically and be open to public debate. In particular, the inclusion of some public infrastructure endowments, whose impacts on local resident welfare seem low, should be reconsidered. In parallel, the amount made available for equalisation should no longer be derived as a fixed share of national tax revenues. This would help to avoid increases in grant entitlements during boom periods that are difficult to cut during recessions.

60. The LAT formula should be redesigned so as to encourage local governments to deliver services in the most cost-effective manner. In the first place, it should be based more systematically on objective needs (e.g. size of school-age population or remoteness indices) rather than on actual endowments, such as the number of schools or length of roads. This would mitigate the incentives for local governments to embark on spending with low economic returns or welfare impacts. The reliance on discretionary elements, including the special LAT and various aspects of modification coefficients used in the LAT calculation, should be reduced and, in general, the formula made more transparent. Similarly, there is a need to remove existing incentives in the LAT system in favour of local bond issues (as the LAT formula takes into account bond repayment costs) because they may hinder otherwise desirable adjustments in local tax rates or cuts in spending. The reduction in the LAT coverage of repayment costs for some public infrastructure (e.g. river and coastal protection as well as agricultural roads) made in FY 2002 is a step in the right direction, as is the increase in the share of local taxes (reservation ratio) retained by prefectures. A bolder reform, however, is needed since a large share (commonly between 35 and 100 per cent) of local bond repayment costs is still paid back by the equalisation scheme while 75 per cent of a rise in local tax revenues stemming from an increase in taxable income is given away to the equalisation pool. 


\section{Increase local government tax autonomy while keeping the tax system as neutral and simple as possible}

61. Increasing local government revenue-raising powers could allow them to better respond to local citizen preferences and, by making the cost of local public services more visible for local taxpayers, to secure fiscal discipline. Before introducing new local taxes, however, the central government should remove barriers to the effective use of local governments' existing powers to set tax rates. First, central government permission for local bond issuance should no longer be conditional on local governments applying local tax rates at, or above, standard tax rates set by the central government. Second, local taxes should no longer be deductible from central government tax bases since this hinders tax competition from playing a role in disciplining local governments. Third, local governments should not fear that changes in local tax rates or efforts to develop the local tax base will be offset by a reduction in grants. This would require limiting the use of discretionary support for those facing financial difficulties (e.g. through the special LAT or the coverage of bond repayment costs by the LAT). Some of the existing ceilings on local tax rates $-e . g$. for the automobile tax - should also be reconsidered.

62. In increasing local government tax autonomy, care should be taken to keep the tax system as simple and neutral as possible. Local governments already rely on a large number of taxes by international standards, the revenue of which is often limited by various exemptions and rebates. In this context, efforts to widen the base of the existing local taxes should take precedence over the introduction of new taxes. Recent steps in this direction have been carried out at the central government level (e.g. the abolition of the special allowance for spouses in the national personal income tax) and should be pursued. Since local governments often piggy-back on central government taxes, these reforms would have beneficial trickledown effects at the local level. There is also some scope to increase local government revenues from taxes on immovable properties whose proceeds, as a share of GDP or total taxes, are still below the level in Canada, the United Kingdom and the United States. This would require bringing the property value for tax purposes into line with the actual value once the market cycle has normalised. On the other hand, reducing the complexity and increasing the transparency of the local tax system requires imposing limits on local governments' ability to introduce special and ad hoc tax exemptions, in particular for taxes on businesses.

63. Local government reliance on taxes which are highly volatile, can be easily shifted to nonresidents or are unevenly distributed, should be avoided. Concerns have been expressed that several of the "supra-legal taxes" introduced after the 2000 amendment of the Local Taxation Act score low in at least some of these respects. These taxes also add to the complexity of the tax system. This would call for a reassessment of the benefits and limits of the system of supra-legal taxes. Efforts to rationalise existing local business taxes, which are numerous and often overlap, would also be desirable while recognising that local taxes on business assets and value-added may have serious drawbacks for the economy as a whole.

\section{Harden fiscal rules and strengthen the role of financial markets to ensure fiscal discipline}

64. As at the central government level, there is an urgent need to restore fiscal sustainability at the local level, and to contain debt in particular. The central government has announced that from FY 2006 it will remove the approval system for local bond issues. While this may have a positive impact on local government fiscal discipline by weakening the implicit guarantee on their bond issues, it will deprive the central government of a direct control instrument over local debt. This calls for a strengthening of other instruments - fiscal rules and/or market instruments - to discipline local government fiscal behaviour.

65. Existing fiscal rules should be gradually hardened, and their coverage broadened. While local government debt as a share of GDP in Japan is one of the highest among OECD countries, fiscal rules have remained rather lenient. The rule on local government financial balance ("net revenue") should be tightened in two main respects. First, it should no longer consider local bonds as a source of revenue for local governments. A rule on the operating balance would be highly preferable. Second, the existing 
ceilings for this rule should be brought down significantly. In parallel, the existing ceiling on debt servicing costs should be made more binding by no longer excluding interest payments and certain categories of bonds from the rule and, once the current level of total debt servicing costs is recognised, by setting a downward path.

66. To be credible, fiscal rules should embody some elements of flexibility and sanction mechanisms. The existing ceiling on debt servicing costs, by being based on a past three-year average, already contains a medium-term perspective. A similar degree of flexibility should be built into the deficit rule, the more so because the current set of local taxes display high volatility. This would serve to avoid having local governments behave in a pro-cyclical manner (e.g. increasing taxes or cutting spending when the economy slows). Enforcement mechanisms may also be required to strengthen local government incentives to comply with fiscal rules. A necessary action is to reconsider existing financial supports to local governments facing financial troubles, including discretionary grants (the so-called special LAT when local governments are under a financial rehabilitation plan) and the access to subsidised bonds, which could create moral hazard problems.

67. Financial markets should also play a more prominent role in enhancing fiscal discipline at the local level. This would require reducing further the amount of local bonds bought by public institutions, which currently play a dominant role in setting the conditions for bonds underwritten by private banks and those publicly advertised. The central government should also ensure that adequate information on local government financial positions is available and recognise differences in the creditworthiness of local bonds. It may be difficult to exclude some bail-outs of local governments facing serious financial problems in Japan, where local governments provide core public services with relatively high minimum standards imposed by the central government. Nevertheless, not all local bonds should be given an implicit guarantee from the central government.

68. For financial markets and fiscal rules to exert effective discipline on local government borrowing, adequate information on borrowers' outstanding and implicit liabilities, as well as on their repayment capacity, must be readily available. The central government should request local governments to disclose information on their implicit liabilities, including those associated with retirement allowances for local public employees, as well as net assets of local public enterprises and the so-called "third-sector companies" (valuing assets at their current prices). In addition, stricter rules for risk-sharing in the contracts for public-private partnerships (third-sector companies) should be implemented and, if appropriate, the companies should be closed or privatised. 


\section{References}

Akai, N. (2003a) "On the Factor of Bankruptcy of Japanese Third Sector", ESRI Discussion Paper Series No. 32, Economic and Social Research Institute, Cabinet Office, Government of Japan.

Akai, N. (2003b), "On the Factor of Bankruptcy of Japanese Third Sector' (in Japanese), ESRI Discussion paper series No. 32, Cabinet Office.

Akai, N., M. Sato and K. Yamashita (2004), "Soft budgets, excessive costs and intergovernmental transfers: a stochastic frontier analysis on local public service production in Japan", mimeo.

Akai, N., M. Sato and K. Yamashita K. (2001), "Intergovernmental transfers in Japan and soft budgets", in Proceedings for International symposium on intergovernmental transfers in Asian countries: practice and issues.

Bassanini, A., S. Scarpetta and P. Hemmings (2001), "Economic Growth: the role of policies and institutions - panel data evidence from OECD countries", OECD Economics Department Working Paper, No. 283.

Cabinet Office (2001), Annual report on the Japanese economy and public finance, 2000-01.

Cabinet Office (2004), Report on the Assessment of Structural Reform, No. 2 (in Japanese).

Council of Local Authorities for International Relations (2002), Local government in Japan.

DeWit, A. (2002), "Dry rot: the corruption of general subsidies in Japan", Journal of the Asia Pacific Economy, Volume 7, Number 3, October, 2002, pp. 355-78.

Doi, T. (2001), “An empirical analysis on bond issuance approval system", The Journal of Social Science, Institute of Social Science, University of Tokyo.

Doi, T (2002), "System and role of local bonds permits in Japan", in Government deficits and fiscal reforms in Japan, T. Ihori, T. Doi, R. Ray Kato, H. Kondo, H. Nakano, T. Nakazato and S. Sato (ed.). Boston, MA: Kluwer Academic Publishers.

Doi, T. and T. Hoshi (2002), "Paying for the FILP", NBER Working Paper Series, No.9385, December 2002.

Doi, T. and T. Ihori (2002), "Fiscal reconstruction and local interest groups in Japan", Journal of the Japanese and International Economics, 16, pp. 492-511.

Doi, T. (2004), “A missing link in Decentralization reform in Japan: 'Trinity Reform Package' ”, Policy Research Institute, Ministry of Finance, Discussion Paper, April 2004.

Economic Planning Agency (1998), Research on inward investment promotion measures at the local level, research delegated to Nippon Credit Bank Research Institute.

European Business Community (2003), Promoting foreign investment through decisive reforms - the EBC report on the Japanese business environment 2003. 


\section{ECO/WKP(2005)3}

Hayashi, M. (2002), "Congestion, technical returns and the minimal efficient scales in local public production: the case of Japanese municipalities".

Hayashi, T. (2004), "Discipline on Local Public Finance: Market or Fiscal Rules?" (in Japanese), ESP No. 384, Association for Economic Planning, Tokyo.

Higo, M. and Y. Nakagawa (2001), "Problems with local individual projects and the LAT system - good and bad effects of financial support measures to local government by the LAT" (in Japanese), Working Paper 01-9, Research and Statistic Bureau of the Bank of Japan..

Imai, Y. (2002), "Health care reform in Japan”, OECD Economics Department Working Paper No. 346.

Ishii, H. and E. Wada (1998), "Local government spending: solving the mystery of Japanese fiscal packages", Institute for International Economics, Working Paper 98-5.

Japan Credit Rating Agency (2002), Credit rating on local bonds (in Japanese).

Joumard, I. and P.M. Kongsrud (2003), "Fiscal relations across levels of government", OECD Economics Department Working Paper No. 375.

Kamada, K., N. Okuno and R. Futagami (1998), "Decisions on regional allocation of public investment: the case of Japan", Applied Economic Letters, vol. 5.

Kitamura, W. (2002), "The paradox of centralization, and the paradox of decentralization: institutional impact of central-local relations on local governance in Post-War Japan".

Kondo, H. (2002), "Public works", in Government deficit and fiscal reform in Japan, Ihori and Sato (Ed.), Boston, MA: Kluwer Academic Publishers.

Le Saout, R. (1998), Les enjeux de l'intercommunalité, La documentation française, Paris.

Mihaljek, D. (1997), "Japan", in Fiscal federalism in theory and practice, ed. T. Ter-Minassian, International Monetary Fund, Washington.

Ministry of Finance (2001), "Report by a Study Group on self-supporting regional economies and public investment" (in Japanese), Policy Research Institute.

Ministry of Finance (2002), "The role of government in regional development - A consideration of productivity and the creation of jobs", Research report summary, press release, 17 June 2002.

Ministry of Finance (2003), Current Japanese fiscal conditions and issues to be considered..

Ministry of Public Management, Home Affairs, Posts and Telecommunications (2002), White paper on local public finance, 2002.

Ministry of Public Management, Home Affairs, Posts and Telecommunications (2004), "White paper on local public finance, 2004" (in Japanese).

Mochida, N. (1998), "An equalization transfer system in Japan”, in The welfare state, public investment, and growth, Shibata and Ihori (eds.).

Mochida, N. (2001), “Taxes and transfers in Japan’s local finances”, World Bank Institute. 
Mochida, N. (2004), Fiscal Decentralization and State-Local Finance: Fundamental perspectives (in Japanese), University of Tokyo Press, Tokyo March 2004.

Muta, H. (2000) "Deregulation and decentralization of education in Japan", Journal of Educational Administration, 38(5).

Nagaosa, M. (2003), "Challenging tax reform in Japan”, paper presented at the Banca d'Italia Research Department Public Finance Workshop, Perugia 3-5 April 2003.

Nakano, H. (2002), "Local bond system and fiscal discipline - Distortion in local bond approval system through LAT repayment measures" (in Japanese), Financial Review, No. 61, Policy Research Institute, Ministry of Finance.

Nakazato, T. (2003), "Public infrastructure and economic growth: an empirical analysis of the long-run effect of road investment", ESRI Discussion Paper series No. 51.

Nicoletti, G., S. Golub, D. Hajkova, D. Mirza and K.-Y. Yoo (2003), "Policies and international integration: influences on trade and foreign direct investment", OECD Economics Department Working Paper No. 359.

Norinchukin (Central Cooperative Bank for Agriculture and Forestry) Research Institute (2002), "Price differences among local government publicly advertised local bonds" (in Japanese).

Norinchukin (Central Cooperative Bank for Agriculture and Forestry) Research Institute (2003), "Current situation of the local bond market" (in Japanese).

OECD (1997), "Managing across levels of government in Japan”.

OECD (2001), New School Management Approaches - what works in innovation in education, Paris.

OECD (2002), OECD Economic Survey of Switzerland, Paris.

OECD (2003), OECD Economic Survey of Japan, Paris.

OECD (2005), OECD Economic Survey of Japan, Paris.

PHP Research Institute (2004), "Issues on the privatisation of postal services and fiscal problems" (in Japanese), Policy Research Report, Vol. 6, No. 77.

Poterba, J.M. and K.S. Rueben (1997), "State fiscal institutions and the U.S. municipal bond market", NBER Working paper 6237, October 1997.

Risk and Investment (2002), "Rating criteria for Japan's local governments refined", News release, October 28, 2002.

Robaschik, F. and N. Yoshino (2004), "Local government finance in Japan: can irresponsible borrowing be avoided?", Duisburg Working Paper on East Asian Economic Studies, No. 72.

Shimizu, K. (2001), Overview, Policy Analysis Series, Education Policy in Japan, No. 4, April 2001.

Söllner, F. (2001), Die anreizwirkungen des länderfginanzausgleichs - eine politökonomische analyse, Konjunkturpolitik 47, 3/2001. 


\section{ECO/WKP(2005)3}

Spiezia, V. (2003), "Measuring regional economies”, OECD Statistics Brief, October 2003, No. 6.

Tax Commission (2003), Annual report to the Prime Minister, December 2003 (in Japanese).

Yoshida, H. (2003). "Reassessing the economic effect of amalgamation of municipalities" (in Japanese), JCER Review, vol. 46, Japan Center for Economic Research, Tokyo.

Yoshino, N. and E. Sakakibara (2002), "The current state of the Japanese economy and remedies", in Asian Economic Papers, Vol. 1, No. 2, Spring 2002. 


\section{WORKING PAPERS}

The full series of Economics Department Working Papers can be consulted at www.oecd.org/eco/Working_Papers/

415. Structural Policy Reforms and External Imbalances (January 2005) Mike Kennedy and Torsten Sløk

414. The Jobs Challenge in Poland: Policies to Raise Employment (January 2005) Andrew Burns and Przemyslaw Kowalski

413. Product Market Competition and Economic Performance in Finland (December 2004) Jens Høj and Michael Wise

412. Oil Price Developments: Drivers, Economic Consequences and Policy Responses (December 2004) Anne-Marie Brook, Robert Price, Douglas Sutherland, Niels Westerlund and Christophe André

411. Wealth Effects on Money Demand in EMU: Econometric Evidence (November 2004) Laurence Boone, Fanny Mikol and Paul van den Noord

410. Banking Reform in Russia : Problems and Prospects (November 2004) William Tompson

409. Public Expenditure in France

(November 2004) Andrew Burns and Alessandro Goglio

409 La gestion des dépenses publiques en France

(Novembre 2004) Andrew Burns et Alessandro Goglio

408. Russian Industrial Restructuring: Trends in Productivity, Competitiveness and Comparative Advantage (October 2004) Rudiger Ahrend

407. Improving the Capacity to Innovate in Germany (October 2004) Andrés Fuentes, Eckhard Wurzel and Margaret Morgan

406. Tax Treatment of Private Pension Savings in OECD Countries and the Net Tax Cost per Unit of Contribution to Tax-Favoured Schemes (October 2004) Kwang-Yeol Yoo and Alain de Serres

405. The Reform of the Health Care System in Portugal (October 2004) Stéphanie Guichard

404. Accounting for Russia's Post-Crisis Growth (October 2004) Rudiger Ahrend

403. Restructuring Russia's Electricity Sector: Towards Effective Competition or Faux Liberalisation? (October 2004) William Tompson

402. Russia's Gas Sector: The Endless Wait for Reform? (September 2004) Rudiger Ahrend and William Tompson

401. One Money, One Cycle? Making Monetary Union a Smoother Ride (September 2004) Peter Hoeller, Claude Giorno and Christine de la Maisonneuve 


\section{ECO/WKP(2005)3}

400. Modelling Cyclical Divergence in the Euro Area: The Housing Channel (September 2004) Paul van den Noord

399. Product Market Competition and Economic Performance in Korea (August 2004) Yongchun Baek, Randall Jones and Michael Wise

398. Product Market Competition and Economic Performance in the United States (July 2004) Hannes Suppanz, Michael Wise and Michael Kiley

397. Saving Behaviour and the Effectiveness of Fiscal Policy (July 2004) Luiz de Mello, Per Mathis Kongsrud and Robert Price

396. The impact of exchange rate regimes on real exchange rates in South America, 1990-2002 (June 2004) Anne-Laure Baldi and Nanno Mulder

395. How Market Imperfections and Trade Barriers Shape Specialisation: South America vs. OECD (June 2004) Joaquim Oliveira Martins and Tristan Price

394. Housing Markets, Wealth and the Business Cycle (June 2004) Pietro Catte, Nathalie Girouard, Robert Price and Christophe André

393. Long-Term Budgetary Implications of Tax-Favoured Retirement Saving Plans (June 2004) Pablo Antolin, Alain de Serres and Christine de la Maisonneuve

392. Enhancing Income Convergence in Central Europe after EU Accession (June 2004) Patrick Lenain and Lukasz Rawdanowicz

391. Asset Price Cycles, “One-Off” Factors and Structural Budget Balances (June 2004) Nathalie Girouard and Robert Price

390. Channels for Narrowing the US Current Account Deficit and Implications for Other Economies (May 2004) Anne-Marie Brook, Franck Sédillot and Patrice Ollivaud

389. Product Market Competition and Economic Performance in Norway (May 2004) Jens Høj and Michael Wise.

388. Product Market Competition and Economic Performance in Sweden (May 2004) Deborah Roseveare, Martin Jørgensen and Lennart Goranson

387. Product Market Competition and Economic Performance in Japan (May 2004) Jens Høj and Michael Wise

386. Migration and Integration of Immigrants in Denmark (May 2004) Deborah Roseveare and Martin Jørgensen

385. Factors Driving Risk Premia (April 2004) Torsten Sløk and Mike Kennedy

384. Rationalising Public Expenditure in the Slovak Republic (March 2004) Rauf Gönenç and Peter Walkenhorst

383. Product Market Competition and Economic Performance in Switzerland (March 2004) Claude Giorno, Miguel Jimenez and Philippe Gugler

383. Concurrence sur les Marchés de Produits et Performance Économique en Suisse (Mars 2004) Claude Giorno, Miguel Jimenez and Philippe Gugler 